Illinois State University

ISU ReD: Research and eData

Theses and Dissertations

9-30-2014

\title{
Padania Or Federalism? An Examination Of The Spatial Demands Of Italy's Northern League
}

Anthony Vincent Pierucci

Illinois State University, avpierucci77@gmail.com

Follow this and additional works at: https://ir.library.illinoisstate.edu/etd

Part of the European Languages and Societies Commons, and the Political Science Commons

\section{Recommended Citation}

Pierucci, Anthony Vincent, "Padania Or Federalism? An Examination Of The Spatial Demands Of Italy's Northern League" (2014). Theses and Dissertations. 263.

https://ir.library.illinoisstate.edu/etd/263

This Thesis is brought to you for free and open access by ISU ReD: Research and eData. It has been accepted for inclusion in Theses and Dissertations by an authorized administrator of ISU ReD: Research and eData. For more information, please contact ISUReD@ilstu.edu. 


\title{
PADANIA OR FEDERALISM? AN EXAMINATION OF THE SPATIAL DEMANDS OF ITALY'S NORTHERN LEAGUE
}

\author{
Anthony V. Pierucci \\ 120 Pages \\ December 2014 \\ This study will analyze what factors affect the oscillation of the spatial demands \\ of ethno-regionalist parties between more moderate and more radical objectives. The \\ factors under examination are electoral, economic, internal organization, and the "other" \\ that the party defines itself against. The study analyzes the relationship between these \\ factors and spatial demands utilizing a case study of the Lega Nord. Ultimately, the study \\ concludes that there is some relation between these factors and the Lega Nord's spatial \\ demands, even if they are not directly causal of the change in spatial demands \\ themselves. The findings also suggest that the generalized findings of party change may \\ not always apply to the spatial demands of ethno-regionalist parties.
}


PADANIA OR FEDERALISM? AN EXAMINATION

OF THE SPATIAL DEMANDS OF ITALY'S

NORTHERN LEAGUE

ANTHONY V. PIERUCCI

A Thesis Submitted in Partial

Fulfillment of the Requirements

for the Degree of

\section{MASTER OF SCIENCE}

Department of Politics and Government

ILLINOIS STATE UNIVERSITY

2014 
(C) 2014 Anthony V. Pierucci 
PADANIA OR FEDERALISM? AN EXAMINATION

OF THE SPATIAL DEMANDS OF ITALY'S

NORTHERN LEAGUE

ANTHONY V. PIERUCCI

COMMITTEE MEMBERS:

Osaore Aideyan, Chair

Noha Shawki

Michaelene Cox 


\section{ACKNOWLEDGMENTS}

The writer wishes to thank the committee chair Dr. Osaore Aideyan and the committee members Dr. Noha Shawki and Dr. Michaelene Cox for their dedication, time, and insights, without which this thesis would not have been possible.

A.V.P. 


\section{CONTENTS}

Page

ACKNOWLEDGMENTS $\quad$ i

$\begin{array}{ll}\text { CONTENTS } & \text { ii }\end{array}$

TABLES $\quad$ iv

FIGURES

\section{CHAPTER}

I. INTRODUCTION 1

Research Question 1

Factors of Interest 2

Contributions of the Study $\quad 6$

Merits and Limitations $\quad 9$

$\begin{array}{ll}\text { Overview of the Chapters } & 10\end{array}$

II. LITERATURE REVIEW 13

$\begin{array}{ll}\text { Introduction } & 13\end{array}$

Party Demands $\quad 13$

External Variables 14

$\begin{array}{ll}\text { Internal Variables } & 18\end{array}$

Internal and External Variables Working Together 20

Party Change: Gaps in Knowledge $\quad 21$

Resurgence of Regionalism $\quad 22$

Ethno-Regionalism 24

Ethno-Regionalist Parties: Knowledge Gaps 26

III. THE LEGA NORD: HISTORY AND CONTEXT 27

From Inception to the Fall of Berlusconi I (1984-1995) 27

From Berlusconi I to the 1999 EP Elections (1995-1999) 31

From the EP Elections to the General Elections of 2013 (1999-2013) 34

The Elections of 2013 and Beyond 37 
IV. THEORETICAL FRAMEWORK 40

Introduction 40

The Electoral Explanation: 'Coalition' and 'Blackmail' Potential 41

The Economic Explanation: Reality vs Perception 46

The Internal Explanation: Individual Level Actions 47

The Identity Explanation: The 'Other' 49

V. METHODOLOGY 53

Introduction $\quad 53$

Lega Nord as a Case Study of Ethno-Regionalism 53

Merits and Limitations of the Case Study $\quad 55$

Data and Methodology: Electoral Factors $\quad 57$

Data and Methodology: Economic Factors $\quad 59$

Data and Methodology: Internal Factors $\quad 60$

Data and Methodology: "Othering" 62

VI. ELECTORAL FACTORS 64

Introduction $\quad 64$

Theory and Hypothesis $\quad 64$

Electoral Performance $\quad 66$

Positions of Other Parties $\quad 69$

$\begin{array}{ll}\text { Conclusions } & 72\end{array}$

$\begin{array}{lll}\text { VII. ECONOMIC FACTORS } & 75\end{array}$

$\begin{array}{ll}\text { Introduction } & 75\end{array}$

Theory and Hypotheses $\quad 75$

Economic Openness vs Spatial Demands $\quad 77$

The Lega's Influence on the Italian Economic Agenda 79

Conclusion $\quad 85$

$\begin{array}{lll}\text { VIII. INTERNAL FACTORS } & 87\end{array}$

$\begin{array}{ll}\text { Introduction } & 87\end{array}$

$\begin{array}{lr}\text { Theory and Hypotheses } & 87\end{array}$

Individual Level Actions $\quad 88$

The Lega Nord and Leadership Change $\quad 91$

$\begin{array}{ll}\text { Conclusions } & 94\end{array}$

$\begin{array}{ll}\text { IX. “OTHERING” } & 97\end{array}$ 
Introduction $\quad 97$

Theory and Hypotheses $\quad 97$

Quantitative Analysis $\quad 98$

Qualitative Analysis $\quad 102$

$\begin{array}{ll}\text { Conclusions } & 108\end{array}$

X. CONCLUSIONS AND IMPLICATIONS 110

Introduction $\quad 110$

Electoral Factors $\quad 110$

Economic Factors $\quad 112$

Internal Factors 112

"Othering" 114

Conclusion 114

$\begin{array}{ll}\text { REFERENCES } & 116\end{array}$ 


\section{TABLES}

$\begin{array}{lll}\text { Table Page } & \end{array}$

1. LN Spatial Demands over Time 55

2. LN Electoral Results, National and EP Elections 66

3. Percent of Manifesto dedicated to Federalism in General Elections 70

4. Economic Globalization in Italy, KOF Index by Year 78

5. Frequency of Internal and External Others in the LN's Visual Propaganda 99 


\section{FIGURES}

Table $\quad$ Page

1. KOF Index of Economic Globalization in Italy 1992-2011 79

2. Lega Nord Homepage, September $2^{\text {nd }}, 2014$

3. 1991 Advertisement for the $1^{\text {st }}$ Congress of the Lega Nord 102

4. Lega Nord Poster from the $1^{\text {st }}$ Secession Period 104

5. Advertisement for Lega Nord Immigration Day 106

6. "We Stopped the Invasion" 107

7. Advertisement for Matteo Salvini’s Basta Euro Tour 108 


\section{CHAPTER I \\ INTRODUCTION}

\section{Research Question}

The resurgence of regionalism in Europe in the late twentieth century shifted the gaze of political science research away from its traditionally state-centric focus to supranational and subnational movements (Fitjar 2010; Johnson and Coleman 2012). Increasingly, more attention has been paid to ethno-regionalist parties as they form across Europe, seeking to alter the balance of power within their respective states. Despite the increased focus on ethno-regionalism in political science research, there are still many gaps in the literature about them, and there is little discussion of the particularities of ethno-regionalist groups in the literature on party change. For example, many factors have been identified that cause changes in party demands, but there is little literature describing what the nature of that change is. Some studies have also shown that the type of party will affect how the party will change as a result of a given stimulus however; ethno-regionalist parties are left out of this discussion. The purpose of this study is to fill these gaps by analyzing the factors that cause the oscillation of the spatial demands of ethno-regionalist parties. This study will also bring into question whether previous research on party change has overgeneralized to the point where it does not apply to ethno-regionalist parties. Specifically it will focus on the following question: What 
causes ethno-regionalist parties to oscillate between more moderate to more radical spatial demands?

Regionalist parties, by definition, seek to alter their relationship with the state they are subject to (Fitjar 2010; Johnson and Coleman 2012). Therefore, spatial demands, demands seeking to alter the territorial relationship between a region with the state, are the central axis of regionalist parties. To answer the question of why ethno-regionalist parties oscillate between more moderate and more radical spatial demands this study will conduct a case study of the Lega Nord (Northern League, LN), a party based in northern Italy. Since its inception the Lega has oscillated between what Régis Dandoy describes as a federalist party (moderate) and an independentist party (secessionist) (2010). In periods when the LN has operated with federalist demands, they attempted to secure more autonomy for the regions of the North by campaigning for devolution of the centralized powers of the national government to the regions. In periods when they have operated as a secessionist party they have campaigned for the secession of several northern regions into a single entity known as Padania (Coleman 1996, Richardson and Colombo 2013). Little research has been done to examine the factors of why ethno-regionalist parties have changed their demands, making this case study an interesting contribution.

Based on the body of literature on ethno-regionalism and party change, this study examines the extent to which several factors, both previously identified and unidentified, have are the Lega Nord's spatial demands. Regarding external factors, the study concludes that the LN behaves as a vote seeking party and it will adjust its spatial demands according to the positions. The study also finds that the LN adjusts its spatial demands based on the position of another party is dependent on the LN's relationship 
with the other party. The economic analysis will examine spatial demands first as an independent factor and subsequently as a dependent factor. The study finds that there is no correlation between the actual state of the Italian economy and the LN's spatial demands. However, when examining the LN's spatial demands as an independent factor, the study concludes that spatial demands affect the ability of the LN to influence the Italian economic agenda. Regarding internal factors there are two findings. The first is that recent leadership changes have brought about new spatial demands and new strategies to attain them. The second is that the high level of concentration of power of the LN has made the individual level actions of the leadership an important factor for the change in spatial demands. The final findings relate to a factor previously unidentified by the literature that can neither be classified as internal or external: the perceived "other". The study does not find evidence to conclude that the "other" is a relevant factor in the oscillation of the Lega Nord's spatial demands. However, when examining the "other" as a dependent factor across different periods of the party's spatial demands, the study concludes that the "other" can be used as a justification for these demands.

\section{Factors of Interest}

The factors of interest in this study encompass both those that have previously been identified as significant to party change, and those yet to be identified. By analyzing the impact of factors that have been previously identified by the literature on party demands the extent to which the factor has an impact can be seen in rich contextual detail, and in certain cases give predictive insight on the possible future political strategy of the Lega Nord. Previously, these factors have only been applied to party demands in general. This study will verify whether or not the generalized theories of party change 
hold true for ethno-regionalist parties. Therefore, the analysis of these factors will also be confirmatory. If the results of the study show the effects of these factors to be insignificant, it would suggest that more research should be conducted to assess whether or not previous theories have been overgeneralized to include the spatial demands and ethno-regionalist parties.

The analysis of factors that have yet to be identified and found to be significant by the literature and their impact on the Lega Nord might warrant further study in a more generalized context of ethno-regionalism. Further study of these factors may suggest that they have a significant effect on the spatial demands of ethno-regionalist parties, or perhaps even demands of political parties in general. However, more than just a single case study would need to be conducted to confirm such a generalization. There are four types of factors of interest in this study. The two external factors are electoral performance and the state of the economy. The internal factor being examined is party personalism, the level to which a party is controlled by one leader. The final factor has both internal and external components and has yet to be studied in relation to party change, the perceived "other".

Giovanni Sartori has argued that parties will behave differently according to their coalition and blackmail potential (1976). Through this study, I expect to find that in times when the Lega Nord has pressed for more moderate spatial demands it is exercising its coalition potential with the Parties Forza Italia (Go Italy, FI) and the Allienza Nazionale (National Alliance, AN), attempting to realistically obtain political power to actualize their policy goals. In periods in which the LN's spatial demands are more moderate, they become a more feasible partner for the center-right coalition. When the Lega Nord has 
pressed for more radical spatial demands it has been exercising its blackmail potential, attempting to remain relevant by taking votes away from established parties. As other parties begin to adopt policy stances on issues that had previously been exclusive to the $\mathrm{LN}$, the party will begin to lose relevance. The adoption of radical spatial demands sets the Lega apart from other parties, reestablishing its relevance as a political entity. However, this is done at the expense of being a feasible partner in a governing coalition, making it difficult for the $\mathrm{LN}$ to realistically achieve its political goals.

Though the literature has recognized the oscillation in the Lega Nord's demands, there has been little research that has attempted to understand these shifts. There is also little research that examines the Lega Nord after the fall of the third Berlusconi government, which was the last time the LN has been part of a ruling coalition. This study, which will examine the entirety of the Lega's spatial political demands to present day, finds that the Lega has entered a new phase of spatial demands, calling for outright secession. Should my hypotheses be supported through this study one could reasonably predict that the $\mathrm{LN}$ is headed towards another secessionist phase due to electoral losses to the Movimento di Cinque Stelle (Five Star Movement, M5S). The examination of the factors related to the electoral system may have predictive implications along with explanatory implications.

This study will also examine Italian economic openness in relation to the LN's spatial demands. Previous other scholars have noted that economic factors and economic globalization can have an impact on party change (Haupt 2010; Ezrow and Hellwig 2012; Schumacher, de Vries, and Vis 2013). However, this study finds that the Lega Nord behaves as a vote seeking party. Therefore, the actual state of the economy is not as 
important as the voter's perception of the economy. The study will confirm the hypothesis that there is no correlation with data regarding Italy's economic openness and the LN's spatial demands. The two may not be unrelated, however. This study will examine how the Lega Nord's spatial demands have either allowed or inhibited the LN from influencing the Italian economic agenda.

Internal factors, those that stem from the party or its structure, can also have an impact on the demands of a party (Harmel and Janda 1994). Harmel and Janda identified two key internal factors in their analysis of party goals: leadership change, and change in dominant factions (1994). Through my analysis of the Lega Nord, I expect to find that these factors do not have as great of an impact on their spatial demands as the external factors, as for most of the Lega Nord's history these factorss have remained constant. The LN has only had two changes in their leadership, with its founder, Umberto Bossi, running the party since its inception in 1984 to 2012, when Roberto Maroni became the party leader. Subsequently, in December of 2013, Matteo Salvini defeated Bossi in an election for Party Secretary and currently holds the title. The Lega Nord is incredibly hierarchical, which has made factions within the party virtually nonexistent (Cento Bull and Gilbert 2001). This study finds that under the extreme concentration of power in the party leadership, the change in the individual level preferences of Umberto Bossi have had an impact on the LN's spatial demands. The study also finds that the change in party leaders has also been a relevant factor for determining the Lega Nord's spatial demands and strategies for achieving these demands.

It has been theorized that in order for group identity to be established there must be some conception of an "other" which a group can differentiate itself from (Abizadeh 
2005; Woods 2009; Woods 2010; Johnson and Colman 2012; Richardson and Colombo 2013). This makes the "other" a part of group identity. Theoretically, a change in a group's conception of the "other" could alter the group's own identity. Through the case of the Lega Nord This study examines whether the party's spatial demands will oscillate with its conception of the 'other'. The study hypothesizes that in times when the Lega Nord campaigns for more radical spatial demands, such as secessionism or autonomy, the LN's conceptualization of the other will be internal, such as the Italian central state or the southern regions of Italy. In periods in which the Lega has more moderate spatial demands, such as federalism, the 'other' they present themselves against will be external, such as the European Union or immigrants. Ultimately, this study does not find evidence to confirm this hypothesis. Through a qualitative analysis the study does find that the "other" has been used to justify the spatial demands of the LN.

\section{Contributions of the Study}

This study will contribute to the body of knowledge on party demands by examining the impacts of previously identified factors in rich contextual detail to assess their impacts in a specific scenario. This study will also identify factors that have not yet been attributed to changes in party demands by analyzing the impact on the Lega Nord. There is a large body of literature on the theory of 'othering' and its role in the formulation of group and national identity. This study will examine the relationship between "othering" and its spatial demands. This study will not only assess the effect of 'othering' on the LN's ethnic identity, but its spatial demands as well. Although other studies have shown internal factors to be important to party demands, few studies have examined how the individual level actions of party leaders have caused party change. 
This study will contribute to the literature on ethno-regionalist parties by demonstrating how changes at the individual level of party leadership can have an impact on spatial demands. From a purely comparative perspective, this study contributes to our knowledge of the dynamics of self-determination and secessionist struggles.

Applying previously identified factors, such as electoral support, to the case of the Lega Nord also gives the study some predictive power. If the hypotheses of this study are found to be true, then another oscillation towards more radical spatial demands can be expected, as new parties enter into the Italian political arena. One of these parties is beginning to take ownership of the anti-politics issue away from the LN. This could potentially cause the Lega Nord to oscillate toward secessionism once again to remain relevant. Although literature on coalition and blackmail potential on party demands is extensive, examining this factor in the case of the LN could contribute some predictive insight for researchers in the field of Italian politics.

The examination of the factor of economic openness will yield an understanding of how the LN behaves as a vote seeking party. The findings refute previous theories suggesting that parties are responsive to economic factors. This suggests that these theories may have overgeneralized their findings to include ethno-regionalist parties. In order to assess the relationship between economics and spatial demands the study then examines the LN's spatial demands as the independent factor, and the success of their economic policies as the dependent factor. The study finds that when the LN has had more moderate spatial demands it has been better able to influence the Italian economic agenda. 
Although previous studies have acknowledged the significance of internal factors in their relation to spatial change, the literature has largely ignored actions taken at the individual level by the party's leader. Through the examination of Umberto Bossi's choices as party leader, this study concludes that the actions of party leaders can impact their spatial demands. Through an analysis of the leadership of Matteo Salvini, the current party leader, this study confirms that change in party leadership can also be a relevant factor regarding changes in spatial demands.

Previous studies on party change have ignored the effect of "othering" on the oscillation of spatial demands. This study does not find sufficient evidence to suggest that "othering" is correlated with a change in spatial demands. Although that result was null, there is a relationship found between spatial demands and "othering". When examining the "other as the dependent factor across different periods of the Lega Nord's spatial demands the study finds that the "other" has been used as a justification for these demands.

\section{Merits and Limitations}

The Lega Nord is an ideal case to examine the impact of these factors on the oscillation of spatial demands in ethno-regionalist parties because few ethno-regionalist parties have the longevity or scale of national representation as the LN. The LN also has a weak claim to ethnic identity as Northern Italy has never been a politically or culturally united entity (Cento Bull and Gilbert 2001; Paasi 2009; Cento Bull 2011; Massetti, and Toubeau 2013). Without a solid identity the party's ideology and demands have been unsound and easily subject to fluctuations by other factors (Koff and Koff 2000; Giordano 2004). Therefore, the Lega Nord is an ideal case to examine because there are 
three decades worth of changes in spatial demands to be examined, and its support base is large enough to examine these changes at a national level.

The case study method provides rich contextual detail for the specific case of the Lega Nord. Through examining a specific case in detail, not only can the significance of factors be assessed, but the magnitude of their impact under context specific cases can be assessed as well.

This study does not come without its limitations, however. Although the case study method gives rich contextual detail to a specific case, it does so at the expense of external validity (Lijphart 1971; Collier 1993). The analysis in this study is tailored for the Lega Nord and the Italian political context. It is not a systematic study of commonalities across a multitude of ethno-regionalist parties. Therefore, the findings of this study may not necessarily be generalizable to every case of ethno-regionalism. Generalizations of this study made outside the context of economically developed, parliamentary, European Union (EU) member-states may be misplaced. Even generalizations made in the context of EU members should not be made to hastily, as some of the political conditions being discussed may only exist in Italy.

The case study method does not have adequate external validity to make broad generalizations about ethno-regionalist parties. However, case studies are ideal starting points for future research, as they provide the contextual detail that can prove useful in generating hypotheses and building theories (Sartori 1991). Although the case study method may be narrow grounds for making generalizations, the phenomenon of ethnoregionalism is so widespread across Europe that this study may still have implications in regions, such as Scotland, Catalonia, and the Basque region. If the findings of this study 
can be applied to other ethno-regionalist parties in nearby states with many of the same political conditions as Italy, then this study could serve as a starting point for more generalizable theories on European ethno-regionalism. As more research is conducted in other regions across the globe perhaps theories may converge upon more generalized theories. For what this study lacks in external validity it will make up for with detail which will yeild a rich understanding of a specific case, and could also serve as a starting point for more generalizable research as more data is collected.

\section{Overview of the Chapters}

Chapter II will review the relevant literature. It will discuss the state of the body of knowledge on both changes in party demands, and ethno-regionalism. This chapter will provide an overview of consensuses, disagreements, and knowledge gaps that are existent in the literature. This chapter will demonstrate the place that the study will take in a larger body of knowledge.

Chapter III will be the history and context of the Lega Nord in the Italian political system. It will begin with the Lega's inception in 1984 and span until 2014. This chapter will provide the necessary background knowledge for the analysis of the factors by explaining how the Lega Nord's policy stances have changed throughout its existence, and identifying the LN's political adversaries and allies. The chapter will provide rich contextual detail for the case study that will be conducted in the following chapters.

Chapter IV will present the theoretical framework of the study. This chapter will address the knowledge gaps in the literature. Past studies will be drawn upon to formulate hypotheses about the spatial demands of ethno-regionalist parties. 
Chapter V will focus on the methodology of the study. This chapter will discuss the strengths and weaknesses of the case study method. It will also discuss the appropriateness of the case study method for the research question, and the appropriateness of the Lega Nord as the case study. This will be followed by an in-depth explanation of the analysis methods that will be used in chapters VI, VII, VIII, and IX. Finally the section will conclude with the establishment of hypotheses in relation to the Lega Nord, based upon the theoretical framework.

Chapter VI will analyze the effect of the factor of electoral support has had on the Lega Nord's Spatial demands. Specifically, this factor will be looked at through the theoretical framework of coalition and blackmail potential. In this chapter, the Lega Nord's spatial demands will be analyzed alongside their spatial demands. The feasibility of possible governing coalitions will also be assessing by examining the Lega Nord's policy positions versus that of potential coalition partners. Electoral strategies will also be connected with the uniqueness of the Lega Nord's platform.

Chapter VII will focus on the performance related factor of economic success. This chapter will analyze the Lega Nord's policy position in relation to the ability of the LN to deliver on the economic success they posit that their policy platform will create. The chapter will examine economic data in relation to the Lega Nord's position in government, and their spatial demands. This chapter will assess the extent to which the LN's ideology concerning spatial demands was malleable versus their potential for more success in government if they were to take a more moderate stance.

Chapter VIII will examine the impact internal factors have had on the LN's spatial demands. Several of the previously identified internal factors that have been 
shown to cause oscillation in the demands of political parties, such as change in dominant factions or change in leadership, were absent until recent developments occurred. Therefore, this chapter will examine the personality and organizational traits of Umberto Bossi, the former leader of the LN to assess how he kept tight control over party policy, and how he brokered negotiations inside the governing coalitions he was a member of. This chapter will also compare Umberto Bossi to Matteo Salvini, the current leader of the Lega Nord.

Chapter IX will analyze the impact that 'othering' has had on the Lega Nord's demands. This chapter will assess how the Lega's spatial demands have changed between federalism and secession with the LN's conception of the 'other', which has changed between internal and external 'others'. The chapter will demonstrate how the Lega's policy stances and visual propaganda have changed over time, and conclude with an assessment of the results versus the hypotheses.

Chapter $\mathrm{X}$ will be a conclusion of the study and its findings. This chapter will present an overview of the findings of the analysis chapters, and place them in the context of the body of literature on ethno-regionalist parties and party demands. In this chapter predictions on the possible future political strategies of the Lega Nord will be presented based upon the findings. This chapter will also suggest future research topics based on the findings of this study. 


\section{CHAPTER II \\ LITERATURE REVIEW}

\section{Introduction}

This chapter will summarize the existing literature on the demands of ethnoregionalist parties. It will begin by focusing on the literature regarding the demands of political parties. The following section will identify the knowledge gaps in the literature on party demands, and put the research question into context. The subsequent section will discuss the historical rise of regionalism in Europe during the end of the twentieth century, as well as the renewed focus on regionalism, and units of analysis besides the state by political scientists. The chapter will conclude with a discussion of ethnoregionalism and the difficulty scholars have had agreeing on a solid definition, and gaps in the ethno-regionalist literature.

\section{Party Demands}

Angelo Panebianco (1988) asserted that parties do not change their policies arbitrarily. They need some sort of stimulus to motivate change. Change can come at a high cost of human and material resources; therefore, it is reasonable to assume that parties will resist change, and change will only be made under pressure created by some sort of stimulus (Harmel and Janda 1994; Harmel, Heo, Tan, and Janda 1995). Though many theories have been posited in the literature concerning changes in party demands 
and goals, there seems to be a general consensus on two broad categories of variables. Changes in demands and goals occur as a result of external stimuli, and the internal structure of the party (Harmel and Janda 1994; Schumacher, de Vries, and Vis 2013).

External variables are factors outside of party control that the party must adapt to. These can include changes to the party system and electoral results (Harmel and Janda 1994). The literature has found that political parties will respond to external stimuli, and in some cases these stimuli are powerful enough to force a party to reevaluate its goals (Harmel and Janda 1994; Schumacher, de Vries, and Vis 2013).

Internal structural variables pertain to the party organization. These can include leadership changes, factionalism within the party, and the balance of power between the party leadership and its activists (Harmel and Janda 1994; Schumacher, de Vries, and Vis 2013). There is an interaction between the internal and external forces, and this interaction will ultimately determine whether a party's goals will remain static or change (Schumacher, de Vries, and Vis 2013).

\section{External Variables}

Election results have been identified as a powerful motivating factor for change in party positions, as the goal of most parties is to maximize their share of the electorate (Harmel and Janda 1994; Somer-Topcu 2009; Ezrow and Hellwig 2012; Schumacher, de Vries, and Vis 2013). Harmel and Janda's theory of party change (1994) proposed electoral failure increases the likelihood of the party change for vote seeking parties. This proposition was later empirically tested utilizing data from the first postwar election to 1998 of the 23 OECD countries. According to this study, conducted by Zeynep SomerTopcu, parties must balance the potential electoral gain with the potential risk associated 
with party change. Parties will use election results as a source of information on public opinion, and are more prone to switching their positions as a result of electoral losses than electoral gains. This effect diminishes as time passes from the election (2009). Larger electoral losses will cause those with control over party policy to be more open to taking the risk associated with a change in policy (2009). Electoral support is key to a party's survival and one of the most extensively studied external variables in relation to changing party policy.

Another external variable that has been identified by the literature is the political positions of other parties. It is possible that a party may change its goals to better fit in with the norms of the system, possibly resulting in greater acceptance for the party or even increasing their coalition potential (Harmel and Janda 1994). Political parties can influence the policy agendas of other parties, even while in opposition to the governing coalition, through their blackmail potential. Blackmail potential is a concept theorized by Giovanni Sartori (1976), stating that parties could still remain relevant while in the opposition to the governing coalition, so long as they can direct the tactics and policy agenda of the other political parties. One method parties can use to alter other the policy positions of other parties is to coerce them through electoral losses (Evans 2002; Massetti, and Toubeau 2013). For example, the Green Party exercised its blackmail potential in the United States in the 2000 presidential election when it attracted voters from the Democratic Party's base, causing future Democratic candidates to take environmental issues more seriously. Frequently, this tactic is utilized by anti-system parties (Sartori 1976). 
The effect of the positions of rival parties on party change was empirically tested in a study conducted by James Adams and Zeynep Sommer-Topcu (2009). Using data from the Comparative Manifesto Project they found that political parties were indeed responsive to policy shifts of rival parties. Their "Party Dynamics Hypothesis" found that parties tend to move their policies in the same direction as their rival parties. Their "Ideological Families Hypothesis" found that parties were more sensitive to shifts in parties that are ideologically similar to them (Adams and Somer-Topcu 2009). This variable is an example of how the party system itself can have an effect on whether a party will or will not change its demands.

Although several studies have shown the aforementioned variables to have significant impacts on the shift in party goals, this does not necessarily mean that all political parties behave the same. Each political party is unique, and some may have different responses to the same stimuli. Certain stimuli may be considered a political shock for one party, while only a minor adjustment for another (Harmel and Janda 1994). Some studies have shown that certain categories of parties will react differently to the same stimulus. For example, a study by Lawrence Ezrow and his colleagues suggests that certain types of parties will be more responsive to different parts of the electorate. Mainstream parties seem to be responsive to changes in the mean voter, but less responsive to changes in their mean supporters. However, niche parties seem to respond to changes in their mean supporters, but less responsive to changes in the mean voter (Ezrow, De Vries, Steenbergen, and Edwards 2011). Another study showed that niche parties infrequently responded to the changes of the general electorate because they had little incentive to do so, as they were frequently punished at the polls when moderating 
their position (Adams, Clark, Ezrow, and Glasgow 2006). Several grand theories have been made about change in party policy, but as Ezrow and his colleagues have shown there are many nuances that have yet to be explored that relate to the parties themselves.

External variables are not only found within the state, but can be international as well. Another variable that scholars have posited has affected party policy change is the economic conditions, financial actors, and institutions that the party is subject to (Haupt 2010; Ezrow and Hellwig 2012; Schumacher, de Vries, and Vis 2013). The economic forces of the market could in some cases be at odds with the interests of the voters the party is elected to represent (Haupt 2010; Ezrow and Hellwig 2012). The party’s policy agenda could also be at odds with global economic forces, which could cause the party to abandon said policies (Ezrow and Hellwig 2012). This was the case with the French Socialist party in the 1980 's which abandoned their initial socialist program for an economic program more in line with the neoliberal world order (Ezrow and Hellwig 2012). Economic elites also wield a considerable amount of political power, making them difficult for a party to ignore. Economic elites are political actors which compete with the electorate for the attention of political parties (Ezrow and Hellwig 2012).

The level of globalization is another external variable to consider when analyzing shifts in party policy. This variable is not entirely separate from the variable of economic influences, as economies are increasingly becoming globalized, and political parties have been shown to be responsive to globalized economic shifts (Haupt 2010). The world economy is increasingly becoming more integrated, resulting in political parties becoming more dependent on "market elites" for specialized information relating to these new global forces (Ezrow and Hellwig 2012). Ezrow and Hellwig (2012), using empirical 
data from the Comparative Manifesto Project, found that markets that were more exposed to the global economy were less responsive to median voter shifts. Research conducted by Haupt (2010) found that although parties were sensitive to globalized economic shifts, they are sensitive in different ways depending on their level of economic openness. This would suggest that more research needs to be conducted to discover how and why different parties elicit different responses from the same stimuli.

\section{Internal Variables}

Scholars have previously suggested that external performance related variables are informative, but are not enough to completely explain party change (Harmel and Janda 1994; Harmel, Heo, Tan, and Janda 1995). Variables that pertain to the party's organization itself can also have an impact on whether or not a party will change its goals (Harmel and Janda 1994; Harmel, Heo, Tan, and Janda 1995; Schumacher, de Vries, and Vis 2013).

One such internal variable is the level of factionalism within the party and the factions that are dominant. In Harmel and Janda's (1994) “An Integrated Theory of Party Goals and Party Change" the goals of parties are likely to change when there is a change in the composition of the dominant faction. Also according to this theory, as the change in the composition of the dominant party increases the likelihood of party change increases as well. It is quite common for political parties to be composed of factions, which can arise from competition of demands within the party (Harmel and Janda 1994; Harmel, Heo, Tan, and Janda 1995). Harmel and Janda's theory was later empirically tested by Harmel, Heo, Tan and Janda (1995) utilizing data from several parties from Germany and the UK over the period of 1950-1990. Although Harmel found that poor 
electoral performance was a necessary condition for party change, he found that it was not sufficient to explain the entirety of party change. One discovery of his study was the positive correlation between change in the dominant party faction and party change. The dominant faction will implement any changes in party policy (Harmel and Janda 1995). Therefore, when a new faction comes to dominate the party, it is likely that they will have different demands from the previous dominant faction.

Following a similar logic, several sources have identified leadership change as another internal variable that can effect change in a party's goals (Harmel and Janda 1994; Harmel 1995). Leadership change was another variable theorized by Harmel and Janda in 1994 and later confirmed in Harmel, Heo, Tan, and Janda's (1995) study about why political parties change their goals. An illustrative case of the power of leadership change within a party is the Chinese Communist Party, where the party has consolidated its control over the government for decades. However, China has had several leaders with different leadership approaches, which resulted in deep structural reforms (Breslin 2008; Brødsgaard and Grünberg 2013). Although the change in a dominant faction in a political party will result in a change of leadership, a change in leadership does not necessarily imply that there will be a change in the dominant party faction (Harmel and Janda 1994). Therefore, change in leadership is a variable that should be examined separately from change in the dominant party faction.

Recently, another variable related to party organization has been under examination. A study examining 55 political parties in Europe over a time period from 1977 to 2003 found that the organization of power within a party was correlated with its responsiveness to voters (Schumacher, de Vries, and Vis 2013). Two categories of power 
organization were defined: leadership dominated parties and activist dominated parties. Leadership dominated parties were defined as parties in which power was concentrated among a few elites, and there were few internal veto players. Activist dominated parties were defined as parties in which power is diffused among many members of the party and party organizations (Schumacher, de Vries, and Vis 2013). The study found that the leadership dominated parties were more responsive to changes in the median voter, while activist dominated parties were more responsive to changes in voters within the party (Schumacher, de Vries, and Vis 2013). Leadership dominated parties are also more prone to office exclusion (Aldrich 1995; Katz and Mair 1994). This variable has only recently found to be a relevant factor. Therefore, it warrants further study, as to understand if power distribution in a party has effects beyond what has already been studied.

\section{Internal and External Variables Working Together}

The body of literature concerning party change had previously acknowledged the external variables as the primary forces behind party change. Later it became commonly accepted that external factors were not enough on their own to account for these changes, but the internal variables related to party organization also played a role. Recently, some scholars of party change have concluded that the internal and the external variables cannot be entirely separated from each other. The internal and the external variables play different vital roles in the process of party change and can affect one another.

In order for a political party to change there must be some sort of internal reorganization that must occur; however, external variables could be the reason that these internal changes become necessary, relating both the internal and the external variables (Harmel and Janda 1994; Panebianco 1988). Therefore, since some sort of internal 
reorganization is a necessary precondition for party change, it is possible that some party changes could be explained solely by internal variables, but impossible that party change could be caused solely by external factors (Harmel and Janda 1994). External variables may act as stimuli for a response from the party, but ultimately it is the internal variables that will determine the response. According to Harmel and Janda, "[T]he most potent external stimuli are those which cause a party to reevaluate its effectiveness in meeting its primary goal, whether it be electoral success or something else. These externally induced 'shocks' to the party's internal system can catalyze a process of change that reaches more broadly and cuts more deeply than can occur as the result of internal changes...alone" (1994).

\section{Party Change: Gaps in Knowledge}

Despite the extensive body of literature on party change there are still many gaps in the scholarly understanding of the issue. Many variables have been identified that have elicited responses from political parties, causing their policies to shift. However, there are relatively few studies (Haupt 2010; Ezrow, De Vries, Steenbergen, and Edwards 2011; Ezrow and Hellwig 2012; Schumacher, de Vries, and Vis 2013) that have attempted to explain the nature of these shifts. Recent studies have suggested that party ideology, level of appeal, and distribution of power all will affect how a party will respond to a certain stimulus (Ezrow, De Vries, Steenbergen, and Edwards 2011; Ezrow and Hellwig 2012; Schumacher, de Vries, and Vis 2013). Recently, it has become increasingly evident that there is much more to be explored on the topic of party change beyond the grand generalizations. The type of party and its organization has an effect on how parties will respond to variables associated with party change. One category of political party that has 
been noticeably absent from this discussion is ethno-regionalist parties. This study will attempt to explore the nuances of ethno-regionalist party change by examining their central issue, spatial demands.

Another observable knowledge gap in the literature is that many of the relevant variables, not only affect party policy change, but affect each other. It has been theorized that external stimuli can act as a catalyst for party change, though ultimately change will occur as a result of the internal variables (Panebianco 1988; Harmel and Janda 1994). Little research has been done to explain what types of effects these variables have on each other. This study will contribute to this discussion by exploring how leadership structure and concentration of power within a party can impact other internal variables, and thus the party's response to external variables.

\section{Resurgence of Regionalism}

Due to the nascent nature of European regionalism, it is a body of research with many identifiable gaps. In the twentieth century, the height of nationalism, much of the research in political science had a state-centric focus, giving an incomplete account of the complexity of politics at the subnational level (Agnew 2002; Fitjar 2010). However, as the twentieth century drew to a close, it became apparent, especially in Europe, that the nation-state was not the sole source of identity, and increasingly regional identity was becoming politicized, seeking to redefine regional relationships with the state, and causing more academic interest in the study of subnational regions (Fitjar 2010; Johnson and Coleman 2012). Recently, there has been a greater focus on regions as economic units. One reason for this is the exacerbation of interregional disparities as a result of economic globalization (Giordano 2001; Johnson and Coleman 2012). 
Elements of regionalism, such as economic protectionism, were evident in the early $20^{\text {th }}$ century until the 1930s (Paasi 2009). However, after the overt nationalism of World War II, much of the focus returned to the state (Agnew 2002; Fitjar 2010). European regionalism resurged again in the 1990s, and was labeled 'new regionalism' by scholars to distinguish it from the 'old regionalism' from the pre-World War II era (Paasi 2009). The challenge to state-centrism is an essential element of regionalist ideology (Paasi 2009; Fitjar 2010). Globalization has created suprastate regionalism, the idea that the state is too small to effectively function in the global capitalist economy (Paasi 2009; Fitjar 2010). Globalization also caused the resurgence of sub-state regionalism, in which the state is perceived as too cumbersome to be conducive to cultural identification and democracy (Paasi 2009; Fitjar 2010). Both suprastate and sub-state regionalist movements attempt to increase their own power versus the centralized power of the state (Paasi 2009; Fitjar 2010).

Several scholars have attempted to define regionalism. Although these definitions vary, they seem to converge on regionalism as the idea of a territory that attempts to alter its relationship with the state(s) under which they are subject to authority (Dandoy 2010; Fitjar 2010; Massetti and Schakle 2013). Regionalism can be characterized as reactionary, stemming from the desire to defend a region against cultural, ethnic, and economic homogenizing forces (Dandoy 2010; Fitjar 2010; Gould and Messina 2013). Regional identity can arise from cultural, ethnic, or economic differences that the region perceives differentiates it from the state (Agnew 2002; Dandoy 2010; Fitjar 2010; Woods 2009; Woods 2010; Johnson and Coleman 2013). Regionalist parties can be agents of change in the structure of the central government even when they are not represented on 
the national level, which occurs frequently as a result of the particularity of regionalist interests (Massetti and Schakle 2013; Massetti and Toubeau 2013).

\section{Ethno-Regionalism}

Ethno-regionalism, though previously understudied, recently has come to the forefront of research on regionalism, as more ethno-regionalist parties are having an impact on the national stage, especially in Europe (Strmiska 2002). There is considerable debate on what constitutes an ethno-regionalist party. Some scholars consider all subnational forms of regionalism ethno-regionalist, while others argue that ethnic components are not a necessary component of subnational regionalism, making ethnoregionalism a specific case of subnational regionalism (Dandoy 2010). However, there is a broad agreement among two elements of ethno-regionalism that can be used to construct a definition. Ethno-regionalist movements are subnational, have exclusive group identity, and some sort of territorial claim corresponding to its exclusive identity that it desires to renegotiate with the state (Türsan 1998; Cento Bull and Gilbert 2001; Strmiska2002; Dandoy 2009; Dandoy 2010).

Part of the difficulty in assessing what qualifies as an ethno-regionalist party is the question of what constitutes an ethnicity (Cento Bull and Gilbert 2001).To what extent does the movement need to have a solid exclusive group identity, and does this group identity need to be grounded in reality? Theoretically, not all regionalist movements are ethno-regionalist movements (Strmiska 2002). Several scholars have noted that in certain cases ethno-regionalist movements have manufactured their identity (Cento Bull and Gilbert 2001; Albertazzi 2006; Cento Bull 2009; Woods 2009; Cento Bull 2011; Woods 2011). In these cases the historical narrative presented to justify the 
movement's claim to ethnic unity may not be historically accurate or even be logical. If not all regionalist movements are considered ethno-regionalist, are those movements with a "manufactured" ethnic identity to be included?

Even if ethno-regionalism does not include all subnational regional movements there is a wide consensus that ethnicity, even those with long histories, are rooted in imagined communities (Agnew 2001; Fitjar 2010). If ethnic communities are imagined in all cases, then even the movements that have manufactured their ethnic identities, even those which the historical record will not validate should be considered ethno-regionalist as well, so long as they have convinced others around them that they are indeed ethnically unique and have some sort of territorial claim. Ethnicities are as real to the extent that people can be convinced they are real.

Previous attempts to classify ethno-regionalist parties have focused too specifically on the peculiarities of parties; however, Regis Dandoy offers a coherent model of classification, by creating three broad categories based on the severity of the party's demands (2010). The desire for spatial rearrangement, the rearrangement of the distribution of power with between the state and a specific territorial entity, is characteristic of all regionalist parties (Strmiska2002; Paasi 2009; Fitjar 2010). Rather than creating several subcategories of ethno-regionalist parties based on various peculiarities, Dandoy's (2010) typology is all encompassing by revolving around the spatial demands, the demands for spatial rearrangement, of ethno-regionalist movements. These demands are characteristic of all ethno-regionalist parties.

The least radical parties in Dandoy's (2010) typology are the protectionist parties. Protectionists seek official recognition from the state, generally based on cultural or 
linguistic grounds, and an improvement of their situation (2010). The moderately radical category of ethno-regionalist organizations are decentralist parties. Decentralists make the demands of the protectionist parties, as well as challenge the division of authority between the state and the region, generally through a federalist or autonomist framework (2010). The final, and most radical, category is the secessionist parties. Secessionists demand complete detachment from the state(s) in which they are currently subjected to the authority of. This could theoretically occur in the form of complete detachment from one or many states into an independent state, or reattachment to another state which the ethnic movement has ties to (2010).

\section{Ethno-Regionalist Parties: Knowledge Gaps}

With such stark distinctions between Dandoy's categories it can be difficult to place certain ethno-regionalist parties solidly in one group. Since party demands are seldom static the issue could be further complicated if a party's spatial demands were to change. One of the major gaps that Dandoy identifies in his conclusion is the causes that would make a party oscillate between demands (2010). When examining the literature on party demands in general there is little discussion of ethno-regionalism or spatial demands. This study will address the question of why ethno-regionalist parties will change their spatial demands, the demands that the party's identity revolves around. 


\section{CHAPTER III \\ THE LEGA NORD: HISTORY AND CONTEXT}

\section{From Inception to the Fall of Berlusconi I (1984-1995)}

The Lega Nord ${ }^{1}$ was formed in 1984 as a federation of smaller leagues representing the interests and seeking the autonomous status of individual regions in Northern Italy. This early alliance of regional leagues stressed the cultural and economic differences between the North and the South of Italy, and were largely disorganized and loosely centered around the Lega Lombardia (the Lombard League) and their leader, Umberto Bossi (Koff and Koff 2000; Giordano 2001; Cento Bull and Gilbert 2001; Cento Bull 2011; Massetti and Toubeau 2013). The party's leadership is highly personalistic revolving around its founder, and the founder of the Lega Lombardia, Umberto Bossi, a charismatic, controversial, and in some cases unpredictable figure in Italian politics (Gilbert 1993; Cento Bull and Gilbert 2001; Koff and Koff 2000; Giordano 2004; Woods 2010). He has been able to assert tight control over the LN allowing no room for dissent amongst its ranks (Cento Bull and Gilbert 2001). Bossi's persona revolves around his energetic and captivating speech, his working class background, and his utilization of symbolism (Gilbert 1993). He personally had a role in developing the LN's logo, Il Giuramento di Pontidia (The Oath of Pontida), which is a figure of a warrior holding his sword upward, harkening to a $12^{\text {th }}$ Century victory of the Lombards defending Northern

\footnotetext{
${ }^{1}$ Henceforth LN
} 
Italy from the Holy Roman Empire (Gilbert 1993). The party being structured predominantly around one leader is what has made the party's ideological identity weak and its policy positions frequently subject to change (Koff and Koff 2000; Giordano 2004).

The Lega Lombardia immediately experienced electoral success, gaining representation on the provincial assembly in 1985 and winning a Senate seat (given to Umberto Bossi) and sending one representative to the Chamber of Deputies in the Italian general elections of 1987 (Cento Bull and Gilbert 2001). After experiencing success in the European Parliamentary elections of 1989 by forming a 'Northern Alliance', Bossi announced at the Party's national congress the formation of a federation of Northern autonomist parties that would be known as the Lega Nord (Cento Bull 2001; Richardson and Colombo 2013). Realizing the difficulty of mobilizing popular support through the individual leagues, it was at this point the LN increasingly emphasized Northern ethnoregionalism as a whole (Cento Bull 2011). The Lega continued to fare well in the regional elections of 1990, and it was shortly after this victory that the party began to consolidate more as a coherent political party (Koff and Koff 2000; Cento Bull and Gilbert 2001; Cento Bull 2011). In 1992, less than a decade since the formation of the Lega Lombardia, the LN established itself as a major political force on the national stage in the Italian general election, the final election of the First Republic, taking $8.2 \%$ of the national vote and sending 55 representatives to the Chamber of Deputies and 25 Senators to the Senate (Koff and Koff 2000; Cento Bull and Gilbert; Massetti and Toubeau 2013). It is logical that the Lega Nord would gain prominence at this point in history. Corruption was rampant in the Italian government, and globalization had brought changes 
that were unwelcome for many. The Lega Nord's platform addressed these issues. The LN's support base and structure shows strong populist elements, with a strong emphasis on local organizations and ties with local businesses, strong opposition and distrust of the central government, and grassroots organization (Koff and Koff 2000; Giordano 2001; Cento Bull and Gilbert 2001; Giordano 2004; Woods 2009; Woods 2010; Cento Bull 2011; Massetti and Toubeau 2013). Much of their electorate were young working class people living in the Northern industrial alpine regions of Italy (Koff and Koff 2000; Cento Bull and Gilbert 2001; Giordano 2001). With this organizational structure and support base the Lega Nord was able to capitalize off of popular distrust of the Italian government's incompetence, corruption, inefficacy, and taxation rates that did not match the quality of public services (Koff and Koff 2000; Cento Bull and Gilbert 2001; Giordano 2004). It was the engaging organizational structure of the LN, along with the ability of the party to address the people's fears of the Italian political system that allowed them to erode away the political culture of Christian Democrats (DC), which until then had been the dominant political party of the North (Giordano 2004; Cento Bull 2011; Massetti and Toubeau 2013). The mass distrust of the political system would not only cause the rapid expansion of the LN, it would eventually dismantle the Italian party system.

Since the foundation of the first Republic in 1948 the DC had been a part of every governing coalition (Waters 1994; Koff and Koff 2000). The party system of the First Republic insured that the DC would retain this dominance (Waters 1994). Its only major opposition was the Communist Party (PCI), the largest and most established Communist party in Western Europe, and the DC was able to successfully present itself as the only 
democratic option (Waters 1994; Koff and Koff 2000). The fall of Communism and the dissolution of the PCI in 1991, led to public questioning of the loosely organized and highly corrupt DC (Waters 1994). The culmination of the distrust in the Italian political system manifested itself in the Tangentopoli (kickback city) crisis of 1992, in which the judiciary led investigations regarding corruption on thousands of suspects, including some of the highest ranking politicians and business elites (Waters 1994; Koff and Koff 2000). The Lega Nord was able to capitalize off the Tangentopoli crisis because it gave more legitimacy to their anti-state arguments and their portrayal of the Italian political class as corrupt Mafiosi (Cento Bull and Gilbert 2001; Massetti and Taubeau 2013).

The Tangentopoli crisis allowed for rapid passage of electoral reform in 1993, and also led to the dissolution of the party system that had maintained DC dominance since 1948, thus ushering in the Second Republic (Waters 1994; Koff and Koff 2000). In the 1993 local elections it became apparent in the North that the LN, formed less than a decade ago and thought to be a fringe party that would disappear, was of equal strength to that of the DC (Cento Bull and Gilbert 2001). In 1994 a new electoral challenge was posed to the Lega Nord by the newly formed center-right party of Forza Italia (FI), headed by Silvio Berlusconi, which competed for much of the same voting demographic as the LN (Koff and Koff 2000; Cento Bull 2001; Massetti and Toubeau 2013). For the 1994 general elections Berlusconi formed a coalition by utilizing two separate electoral pacts, the Polo della Libertá (Pole of Liberty), with the LN and the Polo del Buongoverno (Pole of Good Government) with the Movimento Sociale Italiano (Italian Social Movement, MSI), a neo-fascist party (Cento Bull and Gilbert 2001). The alliance 
between the regionalist $\mathrm{LN}$ and the statist MSI would ultimately doom this coalition to failure.

In the general election of 1994 the Lega Nord was able to take $8.4 \%$ of the proportional representation votes, making it a major parliamentary force as Berlusconi's victorious coalition came to power (Cento Bull and Gilbert; Richardson and Colombo 2012). The first Berlusconi government (Berlusconi I) was short lived however, due to the inability of the LN to reconcile its differences with FI and the Allienza Nazionale ${ }^{2}$, causing the LN to leave the coalition, and thus the fall of Berlusconi I in 1995 (Coleman 1996; Koff and Koff 2000; Cento Bull and Gilbert 2001; Richardson and Colombo 2012). It was during Berlusconi I that the Lega's disagreements with their coalition began to radicalize some into 'independentists' (Cento Bill and Gilbert 2001). The fall of the first Berlusconi government would lead the Lega Nord to attempt to characterize its former allies, FI and the AN, as rightist radicals (Koff and Koff 2000). This would also lead the Lega Nord to enter a new phase in its spatial demands, campaigning for secession of the North into an imaginary country called 'Padania' (Coleman 1996; Cento Bull and Gilbert 2001; Giordano 2004; Cento Bull 2009; Massetti and Toubeau 2013)

\section{From Berlusconi I to the 1999 EP Elections (1995-1999)}

The Lega Nord, now out of government, needed to construct a new identity for itself as other mainstream parties began to embrace federal reforms (Albertazzi 2006; Massetti and Toubeau 2013). The governing center-left coalition, headed by Romano Prodi, was now implementing gradual federal reforms on leftist terms that would still promote interterritorial equality while sharing more power with the regions; these powers

\footnotetext{
${ }^{2}$ The MSI dissolved and changed its name to the Allienza Natzionale in 1995 in an attempt to break its conflation with its neo-fascist past (Koff and Koff 2000).
} 
included direct election of regional presidents and more autonomy over economic development (Massetti and Taubeau 2013). The Lega Nord now began to campaign for all out secession of the North to create the country of 'Padania' (Coleman 1996; Cento Bull and Gilbert 2001; Giordano 2004; Albertazzi 2006; Cento Bull 2009; Cento Bull 2011; Massetti and Toubeau 2013). On September $16^{\text {th }} 1996$, the Lega Nord presented The Declaration of Independence and Sovereignty of Padania declaring the independence of 11 regions of Northern Italy (Emilia-Romagna, Friuli, Liguria, Lombardy, Marches, Piedmont, Trentino-Alto Adige, Tuscany, Umbria, Aosta Valley, and the Veneto) into a federal republic known as Padania (Lega Lombardia Sezione Origgio). This movement stressed that the ethnic roots of Northern Italy were different from that of Southern Italy (Albertazzi 2006; Cento Bull 2009; Woods 2009; Cento Bull 2011; Woods 2011). The Lega Nord tried to characterize the South as Mediterranean or Roman, while they could not define their own ethnic roots as solidly, as Bossi claimed that the Northern ethnic roots were Germanic and later claimed that they were Celtic (Albertazzi 2006; Woods 2009; Woods 2011).

During this period the Lega Nord was highly supportive of the European Union, seeing it, as many other regionalist groups saw the EU at the time, as part of a framework for creating a 'Europe of Regions' (Giordano 2004). This idea was adopted by several secessionist parties in Europe, and promoted European integration with the regions, not the states, being the main actor (Giordano 2001; Giordano 2004). The EU was originally attractive to the Lega Nord because it was viewed as a mechanism that could undermine the centralized authority of the Italian state (Ibid). The EU had opportunities for the representation of the interests of Northern Italy directly without the interference of the 
Italian state, such as the Council of Regions and the European Parliament (Ibid). One of the greatest fears of the $\mathrm{LN}$ in the late 90 's, and of many Italians, was that Italy would not meet the convergence criteria to join the European Monetary Union (EMU) set to launch in 1999 (Cento Bull and Gilbert 2001; Giordano 2001; Giordano 2004; Albertazzi and McDonnell 2005). Since much of the Lega's support came from Northern small business owners who would benefit greatly from the increased trade of the common currency, the Lega Nord used this as a justification for secession (Giordano 2001; Giordano 2004). Their fears were not confirmed however; as Italy was able to meet the criteria in time to be admitted to the common currency in the first round of admissions (Giordano 2001). In terms of electoral strength, secessionism paid off well for the Lega Nord in the 1996 general elections, receiving $10.1 \%$ percent of the vote, the most the LN has received in any general election (Cento Bull and Gilbert 2001; Giordano 2001; Cento Bull 2009; Massetti and Toubeau 2013). In its strongest constituencies the Lega Nord received over $30 \%$ of the vote, and it was the first place party in Lombardy and the Veneto (Cento Bull 2009; Massetti and Toubeau 2013). Though this position may have given the LN a temporary boost for the election, with the relatively weak support ${ }^{3}$ for the secessionist movement made their territorial claims for the government unrealistic (Cento Bull and Gilbert 2001; Giordano 2004). The LNs secessionist stance puts it in an awkward position where it must balance the ability to achieve actual results for its voters, and its desire to create the state of Padania, which is not likely working in the context of the political system (Giordano 2001; Albertazzi and McDonnell 2005).

\footnotetext{
${ }^{3}$ In a poll conducted in January of $199868.9 \%$ of Northerners interviewed identified secessionism as "unacceptable or disastrous", and $17.4 \%$ identified secession as advantageous but unacceptable (Cento Bull and Gilbert 2001). The Lega Nord may have had strong electoral support however, $86.3 \%$ of Northerners opposed secession, making the demand unrealistic.
} 
The unsustainability of the LN's secessionist position quickly became apparent. Divisions began to appear not only within the party's elites, but between the regions considered to be part of Padania as well (Cento Bull and Gilbert 2001). Debates raged about whether the constitution of Padania should be confederal or federal, and the Liga Veneta preferred an approach that involved working with mainstream parties to achieve an autonomous status for the Veneto within the Italian state, as its neighbors TrentinoAlto Adige and Friuli-Venezia Giulia already had (Ibid). The inability of the Lega to deliver to its constituency became apparent in the 1999 European Parliament (EP) elections, where the $\mathrm{LN}$ received $4.49 \%$ of the vote, a $2.1 \%$ decrease from the last EP election in 1994 (Cento Bull and Gilbert 2001; Massetti and Toubeau 2013; NSD).

\section{From the EP Elections to the General Elections of 2013 (1999-2013)}

After the electoral failure of the LN at the EP elections in 1999, the Lega Nord rekindled its relationship with Berlusconi, joining his new coalition the Casa della Libertá (CdL), which included Forza Italia, the Lega Nord, the AN, and a Christian Democratic Party known as the UDC (Cento Bull and Gilbert 2001; Albertazzi and McDonnell 2005; Massetti and Toubeau 2013). This political alliance was now feasible because of the switch of the Lega Nord's demands to 'devolution' of state authority, and because of a closer personal relationship between Bossi and Berlusconi (Albertazzi and McDonnell 2005; Massetti and Toubeau 2013). This alliance may have saved the LN from becoming completely irrelevant, as they only received $3.9 \%$ of the vote in the 2001 general election, not enough for their defection from the CdL to threaten the Berlusconi government; however, despite being a small party in the second Berlusconi government (Berlusconi II) the LNs members were still given control of several key ministries (Albertazzi and 
McDonnell 2010; Massetti and Toubeau 2013). The Lega Nord's political behavior within the CdL can be characterized as loyal to Forza Italia, but once again antagonistic with the Allienza Nazionale and with the UDC (Albertazzi and McDonnell 2005). Despite their disagreements with the other junior members of the coalition, the Lega Nord served as part of the longest serving parliamentary government in Italian history (Albertazzi and McDonnell 2005). This is remarkable because the coalition contained the Lega Nord, a party that just two years ago campaigned for the breakup of Italy, and the Allienza Nazionale, a party that was born out of the neo-fascist MSI and advocated for a strong central state.

It was during this period that the Lega Nord began to take a strong stance against the European Union (Giordano 2001; Albertazzi and McDonnell 2005). This stark contrast to its previous idea of the 'Europe of Regions' began shortly after Italy's admission into the Eurozone (on time disconfirming the Lega's fears) in 1999, and also as it became increasingly apparent that the EU was headed in a more intergovernmental than supranational direction, and institutions like the COR had relatively little power (Giordano 2001; Woods 2009). The rhetoric of the LN toward the European project now characterized it as a homogenizing force that threatened to undermine the unique local cultures and small enterprise in the North (Giordano 2001; Albertazzi and McDonnell 2005; Woods 2010). The LN no longer represented solely the interests of the North, but the fears of many Europeans about the forces of globalization (Girodano 2001; Albertazzi and McDonnell 2005; Woods 2010).

The fear of globalization can be seen in another issue area that received emphasis from the Lega Nord during this period, a fear which they shared with many of their other 
partners in the CdL, immigration (Albertazzi and McDonnell 2005; Woods 2009;

Albertazzi and McDonnell 2010; Woods 2010; Richardson and Colombo 2012).

Immigration in Italy has expanded rapidly, in fact the number of immigrants tripled in the period between 1991 and 2001 (Colombo 2013). The issue of immigration has been an increasingly salient issue among the Italian population in the past few decades, as it is a relatively recent phenomenon, starting in the 1980s, for what had historically been a largely emigrant country (Colombo 2013). Very few laws existed in Italy to control immigration, and the $\mathrm{LN}$ and the CdL capitalized on this issue by implementing more restrictive immigration policies (Woods 2010; Richardson and Colombo 2012; Colombo 2013).

The Lega Nord's shift from hardline secessionism to devolution and antiglobalization and their cooperation with the CdL paid off electorally. The LN increased their national percentage in the Regional elections of 2004 and the EP elections of 2005 (Albertazzi and McDonnell 2005; Albertazzi and McDonnell 2010). The success of the $\mathrm{LN}$ can be attributed to its ability to cooperate with the CdL, and therefore deliver on policy, and still retain a unique identity within the CdL (Albertazzi and McDonnell 2005). The LN made modest gains in the 2006 general election, receiving $4.58 \%$ of the vote, a .64\% increase from the 2001 general election, and although this electoral gain seems modest the LN was increasing its membership despite the overall decline in party affiliation in Europe (Albertazzi and McDonnell 2010). The 2006 election brought the center-left coalition back into government; however, this government was quickly removed in the 2008 general election (Albertazzi and McDonnell 2010; McDonnell 2013). In 2008 the CdL underwent two significant changes: FI and the AN merged to 
form the Popolo della Libertà (PdL), and the UDC defected from the coalition, leaving the LN and the PdL as the two main parties (Albertazzi and McDonnell 2010; McDonnell 2013; Massetti and Toubeau 2013). This election was a great success for the Lega Nord receiving $8.3 \%$ of the vote, regaining much of the ground the $\mathrm{LN}$ had lost since 1996 and cementing its role as a vital coalition member in the CdL (Albertazzi and McDonnell 2010). The PdL won $47 \%$ of the vote giving the CdL a comfortable majority (McDonnell 2013).

Tensions began to rise between Berlusconi and Gianfranco Fini, the leader of the former AN, causing Fini to form his own party, Futuro e Libertà per l'Italia (FLI) in 2010 (McDonnell 2013). This party alone was not enough to remove Berlusconi III from power, and it was not until the onset of the Eurozone crisis in 2011 did Berlusconi lose enough support to warrant his resignation (McDonnell 2013). The end of Berlusconi III marked the last time that the Lega Nord has been part of a governing coalition. Berlusconi was succeeded by a temporary technocratic government led by economist Mario Monti (McDonnell 2013).

\section{The Elections of 2013 and Beyond}

There is not yet much literature that focuses on the Lega Nord in the period after the fall of Berlusconi III. One of the contributions I will expect that my research will have is to provide evidence for a new, more extreme period of the LN's spacial demands from the central government. From preliminary research it seems that the LN's new leader, Roberto Maroni, seems to be making more radical demands in terms of Northern autonomy. At the State's General of the North, a party conference for the LN, in 2012 Maroni stated that one of his 12 points was to "form a Euroregion of the North, 
Constitutionally self-determined" (Il Sole 24 Ore 29 Sept 2012). The theme for one of their newest campaigns for visual propaganda is "Prima il Nord" (the North First), which may suggest a shift away from the visual propaganda that was largely anti-immigration and anti-EU that Dwayne Woods identified (2009; 2010).

The results of the 2013 general election could also have a profound impact on the LN's spacial demands according to my theoretical framework, which will be presented in Chapter IV. Il Movimento 5 Stelle (the Five Star Movement, M5S), led by comedian Beppe Grillo, is largely an anti-politics movement, and gained the greatest share of the vote. As it will be demonstrated in Chapter VI, the LN received less than half of the share of the vote that they received in the 2008 general election. As noted by previous authors, one of the reasons why many in the North voted for the Lega Nord was out of protest and distrust in the central government. Perhaps the M5S has taken this issue away from the $\mathrm{LN}$, and because the party is not regionalist it could have a much broader appeal as a protest party. If this is the reason for the LN's poor performance in the 2013 general election, then my theoretical framework would suggest that the LN might be headed into a period of more extreme demands in order to remain a relevant party.

In December of 2013, the Lega Nord underwent another leadership change. Matteo Salvini defeated Umbeto Bossi in an election for Party Secretary, the top leadership position in the LN (Agence France Press 2013). He has taken a decidedly antiEU stance claiming that the Euro is a "crime against humanity (Agence France Press 2013). In 2014 Salvini backed other independence movements across Europe, including Scotland and Catalonia (Agence France Press 2014). He is also making waves at the EU 
level by entering into an EP coalition with the National Front in France and several other anti-EU parties across Europe (Agence France Press 2014). 


\section{CHAPTER IV \\ THEORETICAL FRAMEWORK}

\section{Introduction}

This chapter will outline the theoretical assumptions that have guided and will be tested in this study. This chapter will also outline hypotheses about specific variables and their relation to the change in the Lega Nord's spatial demands. The chapter will begin by examining the external variables. It will give a synopsis of Sartori's theories of coalition and blackmail potential. These theories inform the hypothesis that the Lega Nord will augment its spatial demands as an electoral strategy in order to maximize votes. The subsequent section will provide an overview of various theories relating party strategy with economic conditions. These theories will be the basis for the hypothesis that there is no correlation with the reality of economic conditions and the Lega Nord's spatial demands. The following section will focus on theories of how internal variables affect party demands. These theories will inform two hypotheses. The first is that the personal preferences of Umberto Bossi facilitated the ability of the Lega Nord to change its spatial demands. The second is that Matteo Salvini's leadership brought new spatial demands and strategies for achieving them. The final section will examine theories of a variable that does not neatly fit into the categories of external and internal variables: the "other". The theory of "othering" in group identity will inform the hypothesis that when the Lega Nord conceptualizes the 
"other" as an entity within Italy its spatial demands will be more radical than when it conceptualizes the "other" as an entity outside of Italy.

\section{The Electoral Explanation: 'Coalition' and 'Blackmail' Potential}

The first assumption proposed in Harmel and Janda's (1994) An Integrated Theory of Party Goals and Party Change is that "Parties are conservative organizations and resist change", thus change will only occur given a certain stimulus. The theory also proposes that vote seeking parties are more likely to change based on the magnitude of their electoral failures (1994). Later, large $\mathrm{N}$ studies confirmed this proposition using empirical data (Somer-Topcu 2009; Ezrow and Hellwig 2012), and other studies would

go on to identify other variables within the electoral system, such as the policy position of rival parties (Adams and Somer-Topcu 2009), to have an impact on party change. This study will examine the impact of electoral performance and the policy positions of other major Italian parties on the Lega Nord's spatial demands.

The risk of uncertainty associated with policy change is not one that a party is likely to make devoid of adequate information to assess the potential positive and negative repercussions of that change; gauging the public's opinion by analyzing electoral results can be a source of such information (Somer-Topcu 2009). This electoral information can be a source of information for parties, but a later study found that party responses to electoral stimuli were dependent on the party's composition. James Adams and his colleagues found that niche parties tend to respond to changes in the position of their own membership, rather than changes in the median voter as the mainstream parties do (Adams, Clark, Ezrow, and Glasgow 2006). 
The Lega Nord is a niche party, as it has never performed at the levels of the mainstream Partito Democratico (Democratic Party, PD) or Forza Italia (Go Italy, FI), nor does it appeal to the general Italian electorate, as it is regionally based. Although the study of Adams, Clark, Ezrow, and Glasgow (2006) found a correlation showing that niche parties tend to be more responsive to voters within their own ranks, it does not necessarily mean that all niche parties are. There is nothing that by definition would prevent a niche party from responding to electoral results like a vote seeking party from Harmel and Janda's (1994) theory. This raises the questions of whether there are exceptions to Adams, Clark, Ezrow, and Glasgow's (2006) findings and whether the Lega Nord is one of them. ${ }^{4}$

Giovanni Sartori's (1976) theory of coalition and blackmail potential argues that political parties are relevant so long as they can influence policy, regardless of if they are in or out of the governing coalition. Coalition potential is the ability of a party to influence policy decisions through its inclusion in the ruling coalition. This influence becomes stronger if the party's withdrawal would cause the coalition to lose the parliamentary majority. Blackmail is ability to influence the policy agenda of other parties through the threat of electoral losses (Evans 2002; Massetti, and Toubeau 2013). In times when the Lega Nord campaigned for federalism it was attempting to set the policy agenda through coalition potential. In times when the LN campaigned for secessionism it did not believe the statewide parties to be taking federalism seriously enough, and exerted their influence by punishing them through electoral losses.

\footnotetext{
${ }^{4}$ This would be an interesting question to pose, as the Lega Nord was not part of Adams, Clark, Ezrow, and Glasgow's (2006) analysis, though it examined European parties from 1976-1998.
} 
In Sartori's Parties and Party Systems: A Framework for Analysis (1976) he addresses a question that is often taken for granted: what makes a party strong? He posits that many scholars have tried to quantify a specific electoral threshold that would be sufficient to render parties relevant or irrelevant, but according to Sartori "[T]his is no solution at all, for there is no absolute yardstick for assessing the relevance of size...The relevance of a party is a function not only of the relative distribution of power-that is obvious-but also, and especially, of its position of value, that is, of its positioning on the left-right dimension. Thus a party that ranges at the 10 per cent level may well count for less than a party that obtains only a 3 per cent level" (1976). The percentages a party receives can be vital information to assessing the strength of a party, but it is only a single aspect of a party's power to have a meaningful effect on public policy. Sartori identified two other aspects: Coalition potential and blackmail (1976).

Coalition potential is the bargaining power that a party receives through becoming a feasible member of a governing coalition (1976). This power is based on the size of the need of a coalition to obtain a majority, which is related to a party's electoral strength, and the feasibility of the coalition, which is unrelated to a party's electoral strength (1976). For example, it would make sense that parties not included in a coalition that has a sizeable parliamentary majority would have little coalition potential because they have little to offer and would necessitate more compromise within the coalition. It would also make sense that parties of radically different ideologies, such as communists and fascists, would not be likely to join in a coalition together, regardless of the balance of representation in the legislature. Sartori identifies two rules for deciding on a party's 
relevance. The first rule is that a party can be considered irrelevant if it cannot be realistically brought into a coalition (1976).

The implications of coalition potential are apparent in the case of the Lega Nord. In the first Berlusconi government the LN was not able to push through its own policy agenda because the coalition comprising the Lega Nord and the Allienza Nazionale was not feasible. The core ideology of $\mathrm{LN}$ was regionalist while the Allienza Nazionale, composed primarily of members from the neo-fascist MSI, favored a strong central state. Despite being at its electoral height in 1996, it became quickly became apparent that the $\mathrm{LN}$ had relatively no power during its secessionist phase because of its unwillingness to cooperate to form a government as a result of its ideological distance from the other parties (Cento Bull and Gilbert 2001; Albertazzi and McDonnell 2005; Massetti and Toubeau 2013). Despite the strong electoral performance, the LN was unable to form a feasible coalition, and thus unable to govern. Consistent with Sartori's theory, even in periods when the LN has had less electoral support, its coalition potential had made it more powerful, especially when its defection from the government would have caused its collapse as in 2008. In the 2000s the LN moderated its demands, promoting devolution over federalism and was also able to find common ground with the Allienza Nazionale on the issue of immigration (Albertazzi and McDonnell 2005), thus paving the way for a feasible, stable coalition.

The second rule of Sartori's theory is that a party can remain relevant out of government if it has the ability to direct the tactics or direction of political competition (1976). Sartori defines this as blackmail potential, the ability to have relevance in opposition to the governing coalition (1976). Without the second rule party's only have 
relevance so long as they can govern. Theoretically the first rule would discount even major opposition parties as irrelevant. However, the second rule outlines scenarios, in which, opposition parties can utilize strategies to alter the course of political behavior. Sartori notes that blackmail potential is mainly exercised by anti-system parties (1976). Scholars have identified different strategies that parties can utilize to exercise their blackmail potential. One of these methods is to punish major parties by winning over portions of their electorate (Massetti and Toubeau 2013).

This can be seen in the case of the Lega Nord through its position on federalism and its relationship with Forza Italia. The Lega Nord was successful in its early years partially because it was the only party to embrace federal reform (Cento Bull and Gilbert 2001; Massetti and Toubeau 2013). However, in the mid-90s several other parties, on both the right and the left, embraced federal reform in order to attract more votes (Cento Bull and Gilbert 2001; Massetti and Toubeau 2013). They were also able to exercise their blackmail potential when they pulled out of the first Berlusconi government and campaigned on secessionism, winning over much of Forza Italia's Northern electorate in 1996 (Cento Bull and Gilbert 2001; Albertazzi and McDonnell 2005; Massetti and Toubeau 2013).

Both in the cases of parties utilizing their coalition potential and parties utilizing their blackmail potential their power can potentially increase if they can win over a larger portion of the electorate. From a brief overview of the historical record it would seem that the Lega Nord has responded more to external factors in the electoral system than the opinions of their own party. Based on Harmel and Janda's (1994) theory, this study hypothesizes that ethno-regionalist parties will change their spatial demands based on 
electoral factors, specifically poor electoral performance and the policy positions of other parties. If this hypothesis is substantiated through the data it would suggest that the LN does not behave as a traditional niche party, but as a vote maximizing party.

\section{The Economic Explanation: Reality vs Perception}

The economic conditions within a state have been theorized to have an impact on whether or not political parties will change their demands. Existent market forces create new actors that compete for the attention of elected officials, and their interests are sometimes at odds with those of the voters (Haupt 2010; Ezrow and Hellwig 2012). Global economic forces also have the ability to coerce parties to change their demands when they are at odds with the party's policy agenda (Ezrow and Hellwig 2012). Ezrow and Hellwig provide the example of the French Socialist Party in the 1980s, which implemented a strategy to come into line with global capitalism, rather than the agenda of nationalization and redistribution it had campaigned on, in order to fulfill requirements for receiving IMF loans. Economies are becoming increasingly globalized, which has made parties more responsive to economic stimuli worldwide with respect to their policy positions (Haupt 2010). It is clear that economic conditions has some sort of an impact on whether or not a party will change its policy, but how parties will respond to these economic shifts is a question that has been less explored.

If the Lega Nord is behaving as a vote seeking party, the state of the economy could theoretically have an impact on whether or not it will change its spatial demands. However, the primary goal of a vote seeking party is amassing as much electoral support as possible. Therefore, the economy would only have as much of an impact to the degree which it resonated with the voters. It is highly unlikely that the majority of the voters has 
a high degree of technical economic literacy and consistently tracks accurate economic data. It is also possible that the opinions of voters regarding the economy could be manipulated by various interactions via social networks or the media.

It is probable that the majority of the voters in the electorate are not skilled economists, and constantly tracking accurate economic data. If these voters utilizing imperfect information and their opinions can be subject to various manipulations of others through communication, then the decisions the voters reach are not likely to be based on economic reality, but the perception of economic reality. This is the basis for the economic hypotheses of this study. The spatial demands of the Lega Nord will not be correlated to the performance or globalization of the Italian economy; rather it will be correlated with the LN's ability to convince its supporters of an alternative reality.

\section{The Internal Explanation: Individual Level Actions}

While external stimuli serve as a catalyst for party change, ultimately it is the internal factors that will determine how and why the party will react to these stimuli (Panebianco 1988; Harmel and Janda 1994). External factors alone are insufficient to fully understand party change. Several empirical, large $\mathrm{N}$ studies have found internal factors to be significant (Katz and Mair 1994; Aldrich 1995; Harmel 1995; Schumacher, De Vries, and Vis 2013). These factors could include the change in a dominant faction, change in party leadership, and change in the distribution of power between elites and activists.

Change in the leadership of the party, which in some cases could be related to a change in the dominant party faction, has been identified as a factor that can significantly alter party demands. Although change in the dominant party faction will always result in 
leadership change, leadership change is not necessarily a result of a change in the dominant party faction (Harmel and Janda 1994). Harmel and Janda (1994) argue that leadership change can result in a party utilizing new methods to achieve their goals. Leadership change was soon after found to be significant in an empirical study (Harmel 1995).

Studies have shown that the organization of a party can have an impact on its demands. Older studies have shown that parties dominated primarily by their leadership are more prone to office exclusion than others. Schumacher, De Vries, and Vis more recently conducted an empirical study that found the distribution of power within parties to have a significant effect on party change (2013). This study found that parties in which power was concentrated primarily with the party's elites were more responsive to changes in the median voter, and more prone to change in general than parties dominated by their activists, which tend to respond more to changes in their own membership (2013).

Theories and empirical studies have shown that the internal factors of changes in dominant party factions, change in leadership, and the distribution of power can all have an effect on whether or not a party will change its demands. However, all of the previous studies have examined the effects of these variables separately, and do not entertain the possibility that these internal factors might not only have an effect on party change, but possibly on each other as well. In order for there to be competing factions within a party, there must first be space in the party for factions to develop and oppose the dominant faction. The same is true of leadership change. If other potential party leaders cannot criticize or differ with the opinions of the party leadership, then it will allow the current 
leadership to take complete control of the party. In this situation leaders would be likely to be able to keep power for as long as they please, and the leaders that follow are likely to be carbon copies of those before them.

Schumacher, De Vries, and Vis (2013) study the effects of the power differential between leadership and activist dominated parties, but these are the only two distinctions made, when in reality the level of concentration of power in a party is a continuum. Some activist dominated parties can have power concentrated more or less than other activist dominated parties. The same is true of leadership dominated parties. Some leadership dominated parties can have power concentrated more or less than other leadership dominated parties.

The Lega Nord's power structure is frequently described as personalist. This study defines personalist parties as a political party in which internal power is concentrated so heavily in the leadership that most power is concentrated in one leader. These parties frequently become a cult of personality. Based on this logic this study makes two hypotheses. The first hypothesis is that the individual level actions of Umberto Bossi will be a relevant factor for determining the Lega Nord's spatial demands. The second hypothesis is that the leadership of Matteo Salvini will bring about new spatial demands.

\section{The Identity Explanation: The "Other"}

One factor that has yet to be explored by the literature on party change, though has been studied extensively in the literature on group identity, is the concept of "othering". This factor does not easily fall into the category of internal or external factors, as it is caused by the external "other", but the "other" is part of a group's identity. One of 
the earliest conceptions of the theory of "othering" came from Edward Said's work Orientalism (Johnson and Coleman 2012). In his work Said posits that the idea of the 'Orient' is a Western conception, a necessary conception for the West to define itself against (1977). As Europe defined itself against the East "The Orient [became] an integral part of European material civilization and culture" (1977). For Said, despite the fact that the Orient was a Western conception of Eastern culture, it nonetheless took on a real form in the European identity itself.

Johnson and Coleman describe the idea of the "other" as "the intentional construction of a region as different from, perhaps even antithetical to, national norms and values as an element of nation-building" (2012). Much of the literature regarding "othering" is divided between particularists, who believe that there must be an 'other' in opposition to a specific group to construct its identity, and those who argue that the "other" need not be the antithesis of a particular group. Even for those that believe that to construct identity the relationship of the "other" need not be adversarial (Abizadeh 2005), they still acknowledge that identity is based on something that makes one group different than another.

Although there has always been a divide between the Northern and Southern regions of Italy, the LN's platform emphasizes these cultural differences between the regions, thereby, creating separate identities for the Northern regions and the Southern "other". However, the South has not always been targeted as the primary "other" in antithesis to the Lega Nord, as immigrants and the European Union have also been targeted (Giordano 2001; 2004; Woods 2009; Cento Bull 2009; Richarson, and Colombo 
2013). Although the LN never abandons its Northern roots, it seems that immigrants have become the new other, replacing the South (Woods 2009).

The theory of the necessity of "othering" in order to formulate an identity seems to fit the LN and its ability to rapidly change its demands because its identity and claims to a separate ethnicity of "Padanians" is weak. Before the Italian unification Padania had never been a united entity, in fact, Piedmont, one of the regions that the LN claims as a part of Padania, was one of the driving regions of the Italian unification. The Savoy dynasty, the monarchy that united Italy, was the ruling dynasty of Piedmont. The LN's sense of identity is still subject to change and the party has a very flexible decision making structure (Giordano 2001), in fact the specific ethnic roots of Northern Italy that Bossi has claimed has changed between Germanic and Celtic (Woods 2009). With such an unstable identity the LNs perception of its role as a party, and thus its demands are very sensitive to what it considers to be the "other".

This study will connect the group identity theory of "othering" with the subject of party demands by analyzing and if and how it has affected the Lega Nord's spatial demands. Logically it seems that a group that perceived an "other" inside of the state would view the state with less legitimacy, as it would not be likely that the group would view the state as governing a unified people. However, a group that perceived "others" external to the state would be more likely to view the state with more legitimacy and perhaps even nationalistically, as it does not view the state as fragmented. Based on the theory of "othering" this study hypothesizes that when the Lega Nord has identified the "other" as an "other" inside of Italy they will have more radical spatial demands, while in 
periods where the Lega Nord has identified an "other" outside of the state its spatial demands would be more moderate. 


\section{CHAPTER V METHODOLOGY}

\section{Introduction}

This chapter will explain the methodology and data that will be utilized in this study to test the hypotheses presented in the last chapter. The first section will describe the case study of the Lega Nord and why it is an ideal case to examine why ethnoregionalist parties change their spatial demands. The next section will explain the case study method, its merits, and its deficiencies. The following sections will present the research designs and data sources that will be used to answer the hypotheses in the analysis chapters.

\section{Lega Nord as a Case Study of Ethno-Regionalism}

This study will address the question of why ethno-regionalist parties change their demands through a case study of the Lega Nord, an ethno-regionalist party based in Northern Italy. The party's identity has proven to be extremely malleable due to its weak ethnic ties, Umberto Bossi's leadership, and grassroots party structure (Giordano 2001). The Lega Nord's ethnic identity is weak amongst its membership largely because it was fabricated to justify political action in favor of Northern industrial economic interests; the region that the LN claims to be Padania, separate from the Southern Italians, has never in history been politically or culturally united (Cento Bull and Gilbert 2001; 
Paasi 2009; Cento Bull 2011; Massetti, and Toubeau 2013). "Padanian" ethnic identity is so weak that it is largely defined by what it is not, the 'other', than what it is (Woods 2010). The personalistic hierarchy of the Lega Nord, revolving around its charismatic leader, Umberto Bossi, and its grassroots support base, have made the party ideologically unsound and easily subject to change in policy demands (Koff and Koff 2000; Giordano 2004).

The Lega Nord's weak ideology makes it an ideal case study for analyzing the factors that cause ethno-regionalist parties change their political demands because their ideological weakness makes them extremely sensitive to these factors. The frequent oscillations in demands between federalism and secessionism allow for a systematic examination of the factors that cause a change in political demands that would not be possible by examining more ideologically sound ethno-regionalist parties that have infrequently or never changed their demands.

Since its inception the Lega Nord has had four distinct periods regarding their ethno-regionalist demands. Anna Cento Bull identified three of these periods: from 1984 to the collapse of the first Berlusconi government in 1995 the LN campaigned for federalism; from the fall of the Berlusconi government to 1999 the LN campaigned for the secession of Padania from Italy; from 1999 onward the LN campaigned for devolution and fiscal federalism (2009). Since Cento Bull wrote in 2009 new developments have occurred in Italian politics, including the fall of the third Berlusconi government, in which, the Lega Nord was a coalition member. In December of 2013 the Lega Nord reverted back to secessionism. Despite these developments, there is little scholarship examining the behavior of the Lega Nord after the fall of the third Berlusconi 
government. Massetti and Toubeau (2013) predicted that the LN would be taking a secessionist turn. However, there has yet to be a systematic after this development occurred. This study, through the examination the factors that cause ethno-regionalist parties to change their spatial demands, will provide evidence to suggest that the Lega Nord has entered a new period in their political demands.

Table 1: LN Spatial Demands over Time ${ }^{5}$

\begin{tabular}{|c|c|}
\hline Period & Demands \\
\hline $1984-1995$ (Fall of Berlusconi I) & Federalist/Autonomist \\
\hline $\begin{array}{c}\text { 1995-1999 (European Parliament } \\
\text { elections) }\end{array}$ & Secessionist \\
\hline 1999-2013 (Italian general elections) & Moderate Federalism/Devolution \\
\hline 2013-Present & $\begin{array}{c}\text { Autonomist (appears to be taking } \\
\text { secessionist turn) }\end{array}$ \\
\hline
\end{tabular}

\section{Merits and Limitations of the Case Study}

The case study method is appropriate for examining the oscillation of demands in European ethno-regionalist parties because there are a small number of cases for comparison. One of the traits that make the Lega Nord such an interesting case for a study of ethno-regionalism is their ability to become an established force in the Italian political system capable of representation at the national level. When the Lega Lombardia and other Northern leagues began the movement for Northern autonomy in the early 80 's they were not taken seriously by many under the assumption that they, like many other ethno-regionalist parties, were to be a short lived fringe movement (Cento Bull and Gilbert 2001; Giordano 2004). The Lega was also able to capitalize on mass distrust of the Italian political system, and was gaining momentum as the Tangentopoli crises led to

\footnotetext{
${ }^{5}$ Information from 1984-2009 from Cento Bull (2009), the periods following are based on my own assesment

${ }^{6}$ Note: This period of the LN's history of demands has not yet been recognized by the literature. I expect I will find this to be true through my examination of the electoral manifestos and propaganda.
} 
the establishment of the Second Republic, allowing it to establish itself as a major political force on the national stage within just years of its inception (Cento Bull 2001; Massetti and Toubeau 2013). Few ethno-regionalist parties have the longevity or command the influence that the Lega Nord does, making it difficult to conduct a systematic comparative study with such a small number of cases. With a limited number of cases, limited resources, and limited literature, the case study becomes a useful method of inquiry, though it does come with its disadvantages as well (Lijphart 1971; Collier 1993).

One of the main advantages to utilizing a case study is the rich contextual detail that illuminates the particular case that would be lost in a large $\mathrm{N}$ study (Ibid). Given the relatively recent focus on ethno-regionalist parties, the small $\mathrm{N}$ of established parties, and the ambiguity in their classifications, there is a high risk of committing what Giovanni Sartori (1991) defined as concept stretching. This is the idea that loose definitions and the comparisons of cases that are not comparable can lead to poor conclusions (Ibid). Looking at one specific case, in detail can further the understanding of ethno-regionalist parties without concept stretching. Case studies can also be utilized in further research as a building block for more generalizable studies.

Case studies also have disadvantages that need to be acknowledged. One such problem is that case studies have less external validity, and are less generalizable than other methods, such as the statistical that allow for more control (Lijphart 1971; Collier 1993). Without other cases to compare that could possibly falsify a hypothesis, it is difficult to rest a generalizable conclusion solely on a case study (Lijphart 1971). This study by no means suggests that its conclusions will be completely generalizable to the 
oscillation in demands of ethno-regionalist parties. Rather, this specific case has in it the opportunity to analyze a major political movement, and its change over time. As more research on ethno-regionalism is produced or perhaps if more major ethno-regionalist movements occur that have erratic demands, then the conclusions that will be made in this study can be tested outside the context of Italy and the Lega Nord.

\section{Data and Methodology: Electoral Factors}

In the previous chapter it was hypothesized that the Lega Nord change its spatial demands based on factors outside of the party, specifically poor electoral performance and the policy positions of other parties. The data source that will be utilized to test this hypothesis is the Comparative Manifesto Project (CMP) ${ }^{7}$. This source has coded the electoral manifestos of various political parties, including the Lega Nord, based on issues that the manifestos have addressed. This source also provides electoral data for the year the manifestos were released. The CMP has coded electoral manifestos for the LN for all the national elections between 1992 and 2013. They also have the original documents for the 1994, 1996, and 2001 national elections. This data source provides excellent data both qualitatively and quantitatively. CMP does not have data for the Lega Nord manifestos during European Parliamentary years. In order to fill this gap the European Election Database, provided by the Norwegian Social Science Data Services, will be utilized ${ }^{8}$. This will give vital information for the 1999, 2004, 2009, and 2014 European Parliamentary elections.

The two electoral factors that will be examined in this chapter are electoral performance and policy change in other parties. To test whether electoral results have an

\footnotetext{
${ }^{7}$ Data can be accessed at <https://manifestoproject.wzb.eu/>

${ }^{8}$ The European Election Database can be accessed at

<http://www.nsd.uib.no/european_election_database/index.html>
} 
impact on the LN's spatial demands, spatial demands will be compared with previous electoral results in order to determine whether or not they have an impact on their policy position. For the years available (1996-2001) qualitative data will be compared from manifestos in order to obtain a deeper, more contextualized understanding of the spatial shifts taking place. The analysis will begin at 1992, as the CMP does not have data on the Lega Nord's manifestos before this time. This is not problematic, however, as 1992 was the first major breakthrough of the LN on the national stage. In previous elections they did gain many, if any seats in parliament and were primarily a regional power.

To address the question of whether or not the policy positions of competing parties have an effect on the LN's spatial demands data from the CMP will once again be utilized. To test this hypothesis the spatial demands in the Lega's manifestos will be compared to those of its rival parties, specifically Forza Italia (Go Italy, FI), Il Popolo della Libertà (The People of Freedom, PdL), the Ulivo (the Olive Tree coalition), the Partito Democratico (Democratic Party, PD), and Il Movimento di Cinque Stelle (The Five Star Movement, M5S). FI policy positions can be compared with the LN's from its beginnings in 1994 to the election of 2006. Forza Italia then merged with several other minor right parties and became the PdL in 2008, and the CMP has manifesto data for both the 2008 and 2013 elections for the PdL, which will allow for a gapless comparison with the LN. The data for the major parties on the left has more holes however. The data starts with the Ulivo for the 2001 and 2006 elections, and then the PD for 2008 and 2013. Therefore, the comparison with the left will have to begin in 2001, but a gapless comparison can be conducted after this year. The CMP has data on the only electoral manifesto of the M5S in 2013. Therefore the LN will only be compared to the M5S for 
that election. This comparison will be drawn mostly to create an informed prediction about the future of the Lega Nord's spatial demands based on the data analysis.

I expect to find that in periods in which the Lega Nord can address policy issues salient to the public that other political parties are failing to address their spatial demands will be more moderate because they will have greater coalition potential, and thus access to political power. However, if other parties begin to address the same salient issues as the Lega Nord it will revert to more radical spatial demands, such as secession, to remain relevant among the electorate and exercise its power through blackmail, by taking away voters from the more established parties. From analyzing both qualitative and quantitative data regarding the electoral system the relation to the LN's spatial demands can be better understood, and the merits and shortcomings of applying the generalized theories of party change to ethno-regionalist parties.

\section{Data and Methodology: Economic Factors}

Based on the assumption that the Lega Nord is a vote seeking party, it was hypothesized in Chapter III that the state of the economy would have no relation to the Lega Nord's spatial demands. Rather, because the LN behaves as a vote seeking party, the voter's perception of the economy would be a more important stimulus than the actual state of the economy. This hypothesis will be put to the test in Chapter VII using empirical data. The chapter will also analyze how the Lega Nord's spatial demands have allowed or inhibited the party to influence the Italian economic agenda.

To test this question I will use economic data regarding GDP per capita and GDP growth from the World Bank ${ }^{9}$. The World Bank has annual data for these two measures. These measures will be compared against time periods of the Lega Nords spatial

\footnotetext{
${ }^{9}$ Data accessible at <http://data.worldbank.org/country/italy>
} 
demands. I expect to find that these measures will not correlate with the demands of the LN. Qualitative data will also be utilized in order to compare what the LN's perception of the Italian economy is against the actual state of the Italian economy.

Time series data will also be utilized from Swiss Federal Institute of Technology Zurich $^{10}$ on Italy's measure of economic openness. Haupt (2010), as mentioned in Chapter II suggested that parties behave differently depending on their level of economic openness. By comparing Italy's level of economic openness across time, it can be determined whether or not this has an effect on their spatial demands, and what sorts of responses that economic openness elicits from ethno-regionalist parties. Based on the previous hypotheses I expect to find that there is no correlation between the level of economic openness and the LN's spatial demands.

The final portion of this analysis will utilize the historical record as data. This section will analyze how the spatial demands have affected the Lega Nord's ability to influence the Italian economic agenda. Through the analysis of spatial demands as the independent factor and the LN's influence of the Italian economic agenda as the dependent factor the relationship between economics and spatial demands can be assessed. This section will analyze what types of economic policies the LN has supported and actualized in and out of government. This analysis will show how the oscillation of spatial demands can affect the economy, rather than how the economy can affect the oscillation of spatial demands.

\section{Data and Methodology: Internal Factors}

There were two hypotheses mentioned in the previous chapter related to internal variables that will be tested. The first hypothesis is that the individual level actions of

\footnotetext{
${ }^{10}$ Data accessible at <http://globalization.kof.ethz.ch/query/>
} 
Umberto Bossi will be a relevant factor for determining the Lega Nord's spatial demands. The second hypothesis is that the leadership of Matteo Salvini will bring about new spatial demands. These hypotheses will be tested using the case study of the Lega Nord. Though the findings will not be generalizable to all parties using the case study method they could suggest whether these hypotheses are worthy of studying in a more general context. Based on the aforementioned hypotheses it can be expected that Umberto Bossi's leadership will be a key factor in the low leadership turnover and the lack of changes in dominant party factions. It can also be expected that Bossi's actions as a leader will play a role in the change of the LN's spatial demands that the external factors alone cannot account for.

For a case study of the Lega Nord it would not make sense to analyze the previously identified factors of power distribution, change in the dominant coalition, and leadership change in the LN quantitatively. There has been little change in these factors throughout the Lega's existence. Therefore there is not enough quantitative data to assess the impact of these factors. Power has been highly concentrated with the elites, specifically the party's leader. There has also never been a faction in the party that has dissented from this leadership. There is not enough quantitative data on the LN's internal factors for a quality quantitative analysis to be conducted on its relation to spatial change.

The lack of change of these factors during the many years of Umberto Bossi's leadership presents a unique opportunity to study changes at the individual level. Studies examining party change frequently ignore this level of analysis. Due to the high concentration of power under Bossi there were no changes in leadership, dominant party faction, or power structure, effectively controlling for these previously identified factors 
of party change. This study will qualitatively analyze how the personal actions and relationships of Umberto Bossi had an impact on the ability of the Lega Nord to oscillate in its spatial demands.

Recent developments in the Lega Nord have produced two changes of leadership. Umberto Bossi stepped down as party leader in 2012, making way for Roberto Maroni. In December of 2013 Umberto Bossi attempted to reclaim his position as party leader, only to lose in an election to the current leader, Matteo Salvini. This study will qualitatively assess the changes in spatial demands brought about under Matteo Salvini's leadership.

\section{Data and Methodology: “Othering"}

In the previous chapter it was hypothesized that when the LN had conceived the "other" as something internal to Italy it would have more radical spatial demands, and when the Lega perceived the "other" as something external from Italy then it would have more moderate spatial demands. To answer this question both qualitative and quantitative data sources will be utilized based on the Lega Nord's visual propaganda and its manifestos.

Based on the aforementioned hypotheses, it can be expected that the Lega's oscillation in their demands of spatial rearrangement from the central government has been consistent with a change in its perception of the 'other'. One source of data will be from the Lega Nord itself. The LN's website has an archive of visual propaganda organized by year ${ }^{11}$. From this coding will be utilized to determine whether or not a spatial demand or an "other" is being presented in the advertisement, and if so what spatial demand or "other" is being presented. The percentages for certain spatial demands

\footnotetext{
${ }^{11}$ Visual propaganda archive can be accessed at <http://www.leganord.org/index.php/il-movimento/la$\underline{\text { nostra-storia/manifesti?showall=\&start=1> }}$
} 
and "others" will be compared throughout the years in which the visual propaganda is available for. This archive comes directly from the party, therefore, it will be an accurate representation of its demands, as it is a primary source.

Though the Lega's archives will be an accurate data source to make comparisons from, it is not a complete source, as the visual propaganda has only been archived since 2000. Therefore, $\mathrm{LN}$ electoral manifestos will also be examined to see how their policy positions and priorities have changed over time. Once again data will be utilized from the CMP to better answer this question. Numerical percentage data on the frequency of certain issues appearing will be used as well as excerpts from the documents themselves when available. The numerical mention of specific issues will be compared by year in order to assess whether the "other" the LN has identified indeed has changed overtime, and the degree to which the spatial demands have as well.

From this data I expect to find that in periods when the Lega Nord has held more radical demands the 'other' was has been Rome (the Italian central state) and Southern Italy. However, when the Lega Nord has held more moderate spatial demands from the government the 'other' has been Brussels (the European Union) and immigrants. This is not to suggest that I expect to find the old policies preferences or ideology to be completely different from those they held during other time periods. Rather I expect to find that the old ideology and conception of the other will still be present; however, the Lega's conception of the other will shift in emphasis and its prioritization. This analysis will yield knowledge on a factor that has yet to be explored in the literature on party change and that does not fit neatly into the category of internal or external factors. 


\section{CHAPTER VI \\ ELECTORAL FACTORS}

\section{Introduction}

This chapter will examine electoral and party manifesto data in order to test the hypothesis that factors in the electoral system will cause the Lega Nord to oscillate between more moderate and more radical spatial demands. The first section will briefly revisit the theory and hypothesis that were outlined in detail in Chapter IV. The second section will examine data from the European Election Database, provided by the Norwegian Social Science Data Services, versus the LN's historical spatial strategy in order to assess whether or not past electoral performance has played a role. The subsequent section will compare data across election years from the comparative manifesto project. The Lega Nord will be compared with its main electoral competitor Forza Italia in regard to similarities on policy stances, specifically federalism. The final section will examine the results and come to a conclusion about the extent of the impact of electoral factors on the Lega Nord's spatial demands.

\section{Theory and Hypothesis}

Several scholars have noted that factors related to the electoral system can act as motivating factors for party change (Harmel and Janda 1994; Somer-Topcu 2009; Ezrow 
and Hellwig 2012; Schumacher, de Vries, and Vis 2013). One of the most extensively studied of these factors is change in the electorate. In Harmel and Janda's (1994) "Integrated Theory of Party Change" they proposed that for vote seeking parties the greater the magnitude of their electoral loss, the greater the likelihood it is that the party will change. According to Zeynep Somer-Topcu (2009) this is because there is a risk associated with party change. For a party to be willing to assume this risk they need more information about how the public is reacting to their policies, and electoral performance can be a source of this information (Somer-Topcu 2009).

Under the assumption that the Lega Nord behaved as a vote seeking party, I hypothesized in Chapter IV that electoral factors would have an impact on their spatial demands. Specifically in regard to electoral performance, I believe that oscillations in spatial demands will be adjusted in order to maximize votes. As theorized by Harmel and Janda (1994) large electoral losses are likely to result in changes of the LN's spatial demands. The following section will test this hypothesis utilizing data from the European Election Database.

Another electoral factor that has been identified by the literature as having an impact on party change is the policy positions of other parties. The policy position of rival parties has been found to be a relevant factor for party change, especially amongst parties of the same ideological family (Adams and Somer-Topcu 2009). Based on this logic I believe that the Lega Nord will oscillate its spatial demands when other parties begin to adopt similar stances on issues, specifically in regard to federalism.

In this chapter, this hypothesis will be tested utilizing data from the Comparative Manifesto Project. This data source tracks the percentage of electoral manifestos that are 
devoted to specific issues. The Lega Nord's spatial demands will be compared with the percentage of time that is devoted to the issue of federalism for the LN's main electoral competitor Forza Italia and other major Italian parties. Based on the aforementioned hypothesis, it can be expected that change in the LN's spatial demands will be more likely when FI and the other major parties devote less of their manifestos to the issue of federalism.

\section{Electoral Performance}

Table 2: LN Electoral Results, National and EP Elections ${ }^{12}$

\begin{tabular}{|c|c|c|}
\hline Election Year & Election Type & LN \% Share of Vote \\
\hline 1992 & National & 8.65 \\
\hline 1994 & National & 8.36 \\
\hline 1994 & European Parliament & 6.56 \\
\hline 1996 & National & 10.07 \\
\hline 1999 & European Parliament & 4.49 \\
\hline 2001 & National & 3.94 \\
\hline 2004 & European Parliament & 4.96 \\
\hline 2006 & National & 4.58 \\
\hline 2008 & National & 8.07 \\
\hline 2009 & European Parliament & 10.20 \\
\hline 2013 & National & 4.08 \\
\hline 2014 & European Parliament & $6.16^{13}$ \\
\hline
\end{tabular}

Source: European Election Database, Provided by Norwegian Social Science Data Services

\footnotetext{
${ }^{12}$ Some of the data applied in the analysis in this publication are based on material from the "European Election Database". The data are collected from original sources, prepared and made available by the Norwegian Social Science Data Services (NSD). NSD are not responsible for the analyses/interpretation of the data presented here.

${ }^{13}$ This datum was taken from the European Parliament website. It was missing from the EED. <http://www.results-elections2014.eu/en/country-results-it-2014.html\#table02>
} 
The data in Table 2, taken from the European Election Database, contains every national and European Parliament (EP) election that the Lega Nord has participated in from 1992 onward. The Lega Nord had taken part in the 1987 national election however; at this point they were not a major party. Therefore, it is appropriate to begin the analysis in 1992. The elections are sorted by year and labeled as either national or EP elections. The elections that are in white are in periods where the Lega Nord advocated for federalism or devolution, and the elections in grey are occurred in periods when the Lega campaigned on more radical spatial demands.

When examining the data in Table 2, some general trends can be observed. The first is that the Lega Nord's share of the vote seems to remain stable or gradually increase, with the exception of certain times when there appear to be electoral "shocks". I define an electoral shock as a dramatic decrease in a party's share of the vote in comparison to the last election. With the exception of three electoral shocks, in 1994, 1999, and 2013 there has never been a decrease in the LN's share of the vote that has been greater than $0.55 \%$. The decrease in the share of the vote in 2001 and 2006 is so miniscule that it should be considered to have remained stable. However, in 1994 there is a drop of $1.8 \%$ in their share of the vote. In 1999 there is a drop of 5.8\%, and in 2013a drop of $6.12 \%$. Admittedly the shock of 1994 is much smaller than the shocks of 1999 and 2013. However, the Lega Nord lost $1.8 \%$ of the vote in a matter of months in the 1994 EP election, as the EP election occurred in June and the previous general election occurred in March of the same year. Losing 1.8\% of the vote in three months could be very alarming information for a vote seeking party. Still, the 1994 shock was relatively 
modest, which may suggest that other factors were involved with this switch in spatial demands. These factors will be examined in subsequent chapters.

The second trend that can be observed is that the shocks are typically followed by a sizable electoral gain. This can be seen in the 1996 election when the Lega Nord gained $3.51 \%$ share of the vote and again in 2012 when the $\mathrm{LN}$ gained $2.08 \%$ of the vote in only a year. However, the same trend does not occur after the electoral shock of 1999. In fact there is actually a modest decrease in the next election of 2001 of $0.55 \%$. It takes several years for the LN to regain its electoral support after the shock of 1999 . Over the period of 2001 to 2009 the Lega Nord's share of the vote either remains relatively stable or is increasing. This suggests that adjustments were made to the LN's platform that made it more appealing to the mass electorate, even if it did not get the immediate electoral boost that occurred after the shocks of 1999 and 2013. Once again, though the evidence supports this trend, other factors are likely to be at work here as well, and they will be examined in subsequent chapters/sections.

The final trend that can be observed is that changes in spatial demands occur following the electoral shocks of 1994, 1999, and 2013. The colors on the chart, white for moderate demands and grey for more radical demands, change with the electoral shocks. There are no exceptions to this trend for the time period being examined. However, there have only been three oscillations of spatial demands over this period of time, one of which occurred recently. It is possible that more radical demands could result in immediate electoral payoffs, while more moderate spatial demands result in gradual electoral payoffs. Still one should not rush to this conclusion, as there has only been 1 instance in which the LN has switched to more moderate spatial demands. Therefore 
there is not enough data to come to this conclusion. I do not intend to suggest that this trend is guaranteed to continue, but that for now there isn't anything to suggest otherwise, and the data seem to support this trend. As more elections occur and data is collected on them future research should continue to look for anomalies in this trend.

The data from the EED seems to support the hypothesis that oscillations in spatial demands will be adjusted in order to maximize votes. It can be observed in Table 2 that spatial demands are changed immediately following large electoral shocks. Table 2 also shows that adjustments in spatial demands also seem to result in an increase in electoral support. This increase could be immediate in the cases of 1996 and 2014, or it could be gradual, as in the case of 2001. From this analysis, it can be concluded that the Lega Nord does indeed behave as what Harmel and Janda (1994) describe as a vote seeking party. It can also be concluded, consistent with Somer-Topcu's (2009) findings, that the LN has utilized electoral outcomes to inform its decisions regarding party change.

\section{Positions of Other Parties}

Adams and Somer-Topcu (2009) argued that the position of other political parties is a relevant factor for party change. They go on to suggest that parties are more sensitive to shifts within their own ideological family (e.g. parties on the right are more sensitive to shifts in other parties on the right). Based upon the logic of these findings this study has hypothesized that the Lega Nord will oscillate its spatial demands when other parties begin to adopt similar stances on issues, specifically in regard to federalism. Table 3 compares the Lega Nord to another member of its ideological family and the largest party of the right in Italy, Forza Italia. The LN and FI have traditionally competed for the same segment of the electorate (Cento Bull and Gilbert 2001). 
Table 3 presents data for the Lega Nord and the FI/PdL for every general election held in Italy between 1992 and 2013 on the percentage of their electoral manifesto that is dedicated to the issue of federalism. This data was taken from the Comparative Manifesto Project, a data source that codes manifestos to determine the percentage and frequencies of mentions of various issues. The column shaded in grey was the 1996 election, and is shaded because it is the only general election in which the LN campaigned for secessionism (radical demands).

Table 3: Percent of Manifesto dedicated to Federalism in General Elections

\begin{tabular}{|c|c|c|}
\hline Election Year & LN & FI/PdL \\
\hline 1992 & $12.6 \%$ & $\mathrm{X}$ \\
\hline 1994 & $12.6 \%$ & $2.2 \%$ \\
\hline 1996 & $13.8 \%$ & $3.7 \%$ \\
\hline 2001 & $4.8 \%$ & $4.3 \%$ \\
\hline 2006 & $0.0 \%$ & $0.0 \%$ \\
\hline 2008 & $31.1 \%$ & $2.4 \%$ \\
\hline 2013 & $3.3 \%$ & $3.3 \%$ \\
\hline
\end{tabular}

Source: Comparative Manifesto Project

When examining the data in Table 3, it does not seem to support the hypothesis that the Lega Nord's change in spatial demands would occur with oscillations in FI's agenda on federalism. However, this is not to say that FI's stance on federalism had no impact upon the Lega Nord's spatial demands. Adams and Somer-Topcu's (2009) study concluded that parties sensitive to the policy shifts of other parties, and were particularly sensitive to the policy shifts within their own ideological families. They argued that

\footnotetext{
${ }^{14}$ Percentages are taken for FI in 1994-2006 and the PdL in 2008 and 2013 after FI merged with the AN to form the PdL.
} 
parties tend to move in the same direction as other parties within their ideological family. The hypothesis of this study, based on the finding that shifts in other political parties are relevant and the idea that parties can exercise power through coalition and blackmail potential, expected to find that in periods when Forza Italia focused more on federalism it would push the Lega Nord to more radical spatial demands, and when FI focused less on federalism the Lega Nord have more moderate spatial demands.

Table 3 does not seem to support either trend throughout the entire period of the analysis. This does not mean that the idea that other parties of the same ideological family have had no effect on the LN's spatial demands should be rejected. When examining the time period before the 2001 election the Lega Nord does in fact have more radical spatial demands as FI enters the political arena and begins to adopt federalism as a larger share of its platform. After 2001, Adams and Somer-Topcu's argument seems to be correct, as the two parties converge on the issue of federalism (with the exception of the 2008 election which will be explained momentarily).

What could have caused the switch from the LN following a path of divergence with Forza Italia to one of convergence on the issue of federalism? One explanation, which would perfectly align with the data, is that parties will respond differently to the policy shifts of other parties, even those in their own ideological family, depending on whether or not the parties are political allies or foes. Prior to the 1999 EP elections the Lega Nord had been competitive with Forza Italia, and even when the two parties were in a governing coalition together, the relationship was tense and was one of the factors of Berlusconi I's early demise (Coleman 1996; Koff and Koff 2000; Cento Bull and Gilbert 2001; Richardson and Colombo 2012). The switch from the LN as a competitor with FI 
to one of its closest allies occurred after the 1999 EP parliamentary election, with the formulation of the CdL (Cento Bull and Gilbert 2001; Albertazzi and McDonnell 2005; Massetti and Toubeau 2013). The change in the relationship between the Lega Nord and Forza Italia lines up perfectly with the change from divergence on spatial demands to convergence.

One of the reasons this process of convergence seems to occur in the case of the LN after 2001 is because in many of these elections the Lega Nord and FI run on the same manifesto after the creation of the CdL. There appears to be one anomaly in the data after this point in 2008 , when the $\mathrm{LN}$ devote $31.1 \%$ of their manifesto to federalism, while FI only devotes $2.4 \%$ to the issue. Albertazzi and McDonnell (2010) argued that in 2008 part of the reason for the success of the LN was due to its establishment of "issue ownership" over the issues of federalism and security. The Lega Nord became the arm of the CdL that promoted federal and security ${ }^{15}$ reform. Though more research will have to be done across many parties to substantiate the claim that the relationship between parties of ideological families can play a role, the analysis of the Lega Nord in relation to FI highlights the shortcomings of applying generalized models to ethno-regionalist parties and the merits of a thorough case study.

\section{Conclusions}

From analysis of electoral and manifesto data it can be concluded that factors in the electoral system do have an impact on the oscillation of the $\mathrm{LN}$ between more radical and more moderate demands. The spatial demands oscillate after every electoral shock over the period from 1992-2014, suggesting that the Lega Nord does behave as a vote

\footnotetext{
${ }^{15}$ For the Lega Nord this largely meant immigration.
} 
seeking party, and will modify its policy in order to obtain the largest percentage of the vote possible. This would confirm Harmel and Janda's (1994) theory that vote seeking parties adjust their policy demands in order to gain the largest share of the electorate possible, and Somer-Topcu's (2009) claim that parties utilize past electoral data as a source of information to navigate the risks of party change. However, this would also suggest that even though the Lega Nord is a niche party, it does not behave as Adams, Clark, Ezrow, and Glasgow (2006) argued it should. The Lega Nord seems to be trying to maximize its voting base rather than please the supporters it already has.

Though this study's hypothesis that the Lega Nord would become more radical as Forza Italia increasingly addressed federalism was proved to be wrong, however, the data appear to have a sort of pattern that could possibly be grounds for future research. FI did increasingly embrace federalism, and the LN did radicalize their spatial demands, but this process stopped by the 2001 election. After this election a process of convergence between the two parties occurred on the issue of federalism, consistent with trends found by Adams and Somer-Topcu (2009). This might suggest that the relationship between two parties, even of the same ideological family, could have an effect on the way the parties react to each other's policy shifts. This would be an interesting topic for future, more comprehensive research, but is beyond the scope of this study.

Overall, when examining the factors of electoral performance and the position of other parties, it seems that the Lega Nord follows the generalized trends found by large $\mathrm{N}$ case studies only to a certain extent. Upon close examination through a case study, it can be seen that certain niche parties can behave as normal vote seeking parties. The experience of the LN also shows that parties may have different reactions to the policy 
shifts of other parties based on their relationship with them. This data shows that future research should not hastily assume that generalized research on party change to ethnoregionalist parties, especially when it comes to treating them the same as other niche parties. It also highlights the merits of the case study as a method for a deep contextualized understanding of specific political parties and their relationship with other parties in the political system. 


\section{CHAPTER VII \\ ECONOMIC FACTORS}

\section{Introduction}

This chapter will analyze the relationship between economic factors and the Lega Nord's spatial demands. The first section will be an overview of theory that relates economics to party change, and the hypothesis. The second section provides a brief overview of the economic data in relation to spatial demands. This study has hypothesized that there will be no correlation with economic openness and the LN's spatial demands. Therefore, the subsequent section will venture to find if the inverse is true through the use of qualitative data on the past economic policy position of the LN. This section will examine how the Lega Nord's spatial demands have allowed it to influence the Italian economic agenda. The final section will come to conclusions about the relationship between economics and spatial demands.

\section{Theory and Hypotheses}

Globalization's march forward has caused the increased integration and interdependence of economies between states. This is especially true of the memberstates of the European Union. Previous empirical studies have related economic variables 
to party change in general (Haupt 2010; Ezrow and Hellwig 2012). Specifically, they examine the globalization of economics in relation to change in party demands. Haupt (2010) found that as economies globalize that parties become more sensitive to global economic shifts. While Ezrow and Hellwig (2012) found that global economic forces have coercive power to influence political parties to change their policy stances. Both studies note that the interests of the electorate and the interests of economic actors are frequently at odds (Haupt 2010; Ezrow and Hellwig 2012).

In the previous chapter the data supported the claim that the Lega Nord behaved as a vote seeking party. However, Haupt (2010) and Ezrow and Hellwig (2012) found that the interests of the electorate and the interests of economic actors are frequently at odds. For this reason, it would seem unlikely that the Lega Nord could both behave as a vote seeking party and be responsive to global economic forces. It also seems unlikely that a significant portion of the electorate would have enough economic literacy and be tracking accurate data to make their vote based upon complete information of the state of the national/global economy.

Cento Bull (2011) argues that the Lega Nord engages in "simulative politics", in which many of their policy demands are symbolic and emotional in their nature and do not reflect the reality of a newly globalized world. She also notes that even though European economies depend on liberalization of markets to become competitive populist parties have been able to convince a portion of the electorate that protectionist policies would be a viable solution (Cento Bull 2011). This suggests that the Lega Nord may not base its demands about the actual situation of globalization of economies, but what they 
can convince the electorate the state of the globalized economy is and what it can convince the electorate is a feasible solution to these problems.

Based on the idea that the LN, like many populist parties, uses simulative politics as a strategy I have hypothesized that there will be no correlation between the openness of the Italian economy and its spatial demands. However, this does not mean that I expect to find that there is no relationship between economic factors and spatial demands. Based on Giovanni Sartori's theory of coalition and blackmail potential I believe that the Lega Nord's ability to influence the Italian economic agenda will oscillate with its spatial demands. Specifically, this study hypothesizes that when the Lega Nord has more moderate spatial demands its coalition potential will increase, thus increasing its ability to influence economic policy.

\section{Economic Openness vs Spatial Demands}

Table 4 presents data taken from the Swiss Federal Institute of Technology Zurich $^{16}$ on Italy's level of economic openness over time. The table measures the KOF Index of Economic Globalization in Italy over the period of 1992 to 2011. This index measures the level of economic openness of a country on a scale of 1 to 100 with higher numbers indicating greater economic globalization. Once again, the years that the Lega Nord has had more radical spatial demands are shaded in grey.

\footnotetext{
${ }^{16}$ Data accessible at <http://globalization.kof.ethz.ch/query/>
} 
Table 4: Economic Globalization in Italy, KOF Index by Year

\begin{tabular}{|c|c|}
\hline Year & KOF Index of Economic Globalization \\
\hline 1992 & 58.58 \\
\hline 1993 & 64.27 \\
\hline 1994 & 64.92 \\
\hline 1995 & 66.66 \\
\hline 1996 & 67.61 \\
\hline 1997 & 71.67 \\
\hline 1998 & 74.52 \\
\hline 1999 & 74.54 \\
\hline 2000 & 76.53 \\
\hline 2001 & 73.89 \\
\hline 2002 & 72.65 \\
\hline 2003 & 71.42 \\
\hline 2004 & 73.87 \\
\hline 2005 & 72.78 \\
\hline 2006 & 72.48 \\
\hline 2007 & 73.76 \\
\hline 2008 & 72.32 \\
\hline 2009 & 70.56 \\
\hline 2010 & 71.16 \\
\hline 2011 & 70.28 \\
\hline
\end{tabular}

Source: Swiss Federal Institute of Technology Zurich

From examining the data in Table 4 it does not appear that there is any apparent trend relating the level of economic globalization and the Lega Nord's spatial demands. Admittedly the KOF index was at some of its highest levels for this period of time in 
1998 and 1999. However, it climbed even higher the subsequent year when the LN switched to its most moderate demands ever, arguing on a platform of devolution. Also, the original switch to secessionism in 1996 occurred when the KOF Index was 67.61, which is relatively low compared to the KOF Indexes for every subsequent year, which have never dipped below 70.28. When examining Figure 1, presenting visually the information of Table 4, it appears that the switches to secessionism and then back to devolution occurred in a period when the KOF index stabilized between 70 and 77 after a consistent climb throughout the 90's. Based on the data from the Swiss Federal Institute of Technology Zurich, it would seem that economic openness does not have an effect on the spatial demands of the LN.

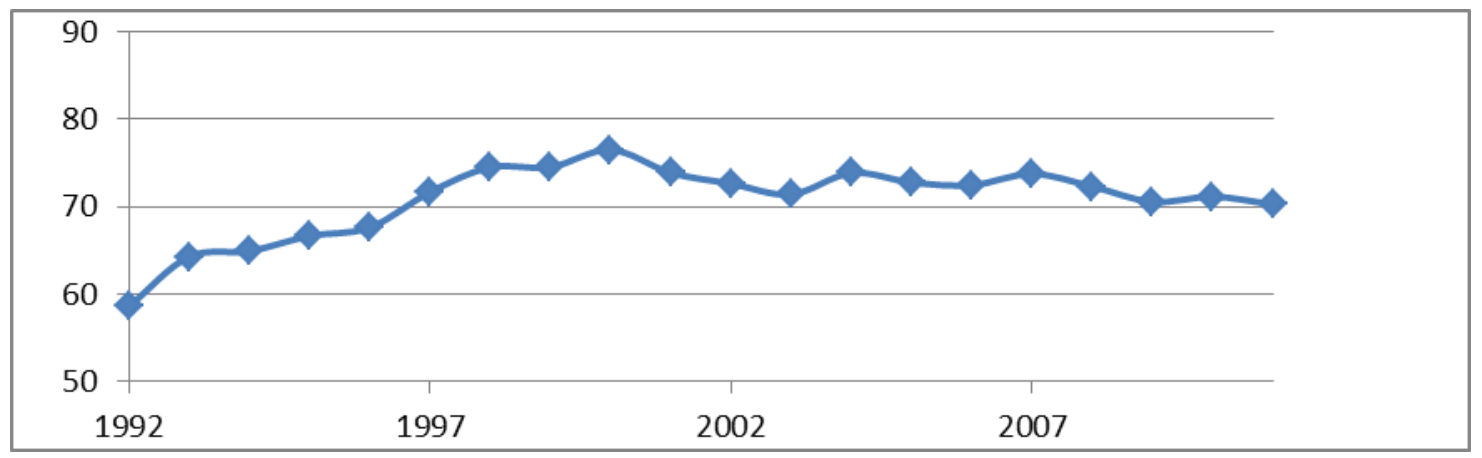

Figure 1: KOF Index of Economic Globalization in Italy 1992-2011

Source: Swiss Federal Institute of Technology Zurich

\section{The Lega's Influence on the Italian Economic Agenda}

The levels of economic openness demonstrate that there is no correlation with the reality of economic openness in Italy and the Lega Nord's spatial demands. Even though the Lega Nord may have been created as a reactionary movement in the face of globalization, economic globalization cannot explain the oscillation in its spatial demands, the core issue of ethno-regionalist parties. This does not necessarily mean that 
there is no correlation between spatial demands and economics, however. The inverse may be true. The Lega Nord's spatial demands seem to have allowed it to impact the Italian economic agenda, specifically through there protectionist policies toward immigrant labor.

The Lega Nord has been able to implement its protectionist economic agenda on the national stage through the issue of immigration. According to the LN's website, without a reaction to illegal immigration, "In this way the doors open to an economically and socially uncontrolled invasion that we cannot sustain anymore ${ }^{17,}$. Massetti and Toubeau (2013) argued that the Lega Nord's ability to influence the territorial agenda can be explained through the electoral logic of Sartori's (1976) theory of coalition and blackmail potential. I agree with this argument and will argue that the Lega's ability to influence the Italian economic agenda follows a similar logic. However, I believe that the LN will only be able to exert economic influence through coalition potential, and that they have been particularly effective in implementing their protectionist agenda through the issue of immigration.

Historically speaking, the Lega Nord has had much more success influencing the policy agenda while it was in government than it had as a protest party utilizing its blackmail potential. In 1994 the LN cemented itself as a force on the national level by entering Berlusconi I with $8.4 \%$ of the national vote, its first ruling coalition (Cento Bull and Gilbert 2001; Richardson and Colombo 2012). The electoral success meant that the Lega had enough representation in parliament to make itself an indispensable junior

\footnotetext{
17 "In questo modo si spalancano le porte ad una invasione incontrollata che, socialmente ed economicamente, non possiamo più sostenere." Source: http://www.leganord.org/index.php/seguici/eventi/referendum Date Accessed: 08/28/2014
} 
coalition member of Berlusconi I. Sartori's (1976) theory of coalition potential states that the coalition potential of a party is determined by two components, the need for more support in the coalition and the feasibility of the coalition. The need for the LN in Berlusconi I was evident, which gave the LN enough coalition potential to be offered a place as a junior member of the coalition. However, there was not enough coalition potential to sustain the coalition, as the Lega Nord's spatial demands made it infeasible. Although not yet at the point of campaigning for the secession of Padania, the LN was uncompromising, making it impossible to cooperate with the statist, neo-fascist junior coalition member, the MSI. This eventually caused Berlusconi I to fall by 1995 due to the Lega pulling out of the coalition (Coleman 1996; Koff and Koff 2000; Cento Bull and Gilbert 2001; Richardson and Colombo 2012).

In 1996 the Lega Nord had begun to openly campaign for the secession of Padania, and had denounced its former allies FI and the AN as rightist extremists (Koff and Koff 2000). This shift in spatial demands did have a sizable electoral payoff in the 1996 general elections when the LN won over 10\% of the vote (Massetti and Toubeau 2013). The Lega now had even more representation than it had when it was a member of Berlusconi I, and the right had need of this representation to form a government. However, this coalition was now even less feasible than the previous coalition. There was now even more animosity between the parties after the fall of Berlusconi I, and the territorial demands that had been the cause of previous tensions between the Lega Nord and the AN had now become even more radicalized.

After the 1999 EP elections, which the Lega Nord experienced a large electoral shock, they were able to reestablish its relationship with Forza Italia, as one if its most 
loyal allies, and joined the CdL coalition, consisting of FI, the LN, the AN, and the UDC (Cento Bull and Gilbert 2001; Albertazzi and McDonnell 2005; Massetti and Toubeau 2013). The Lega had now moderate its demands to the devolution of state authority to the regions (Albertazzi and McDonnell 2005; Massetti and Toubeau 2013). The CdL was more feasible than the previous Berlusconi government, as the LN had moderated its spatial demands, and there was now one coalition rather than two separate electoral pacts forged by FI. The need of the FI for the Lega Nord was not that great, as the LN's pulling out of the government would not have affected its stability. However, the extra support of the Lega made Berlusconi II's stability less fragile.

While in government the Lega Nord was able to establish issue ownership over the issues of federalism and security (Albertazzi and McDonnell 2010). The most central axis to the LN's security policy was immigration. In fact the Lega's focus on immigration gave it more coalition potential by creating an area of agreement and cooperation between them and the AN. This is best exemplified in the passage of the Bossi-Fini Law $^{18}$ of 2002 regulating immigration. One of the major curbs on immigration this law contained was requiring non-EU immigrants to have a work contract signed by an employer providing for round trip travel from and back to the immigrant's home country before a visa could be issued (Paparella and Rinolfi 2002). This poses an incredible hardship for prospective immigrants because they typically take low level work and their jobs require more flexibility (Triandafyllidou and Ambrosini 2011). This law also allowed the Prime minister to set a cap on the number of permits issued in a year and

\footnotetext{
${ }^{18}$ The law was named for Umberto Bossi, the leader of the LN, and Gianfranco, Fini the leader of the AN.
} 82 
made it possible to immediately deport illegal immigrants, and detain suspected illegal immigrants while investigating their identity (Paperella and Rinolfi 2002).

Berlusconi III was the government in which the LN had the highest level of coalition potential than at any other point in its history. This is reflected through the protectionist immigration measures it was able to implement. After winning $8.07 \%$ of the vote the Lega Nord was now indispensable to the Berlusconi Government. Its spatial demands were moderate as well. For the first time both conditions for strong coalition potential were met. They were needed for the government to have a majority in parliament and they were moderate enough to make a feasible coalition with the PdL. The Lega's cooperation with the coalition was rewarded with LN members being given control over key ministries, specifically pertinent to this analysis the Ministry of the Interior (Albertazzi and McDonnell). Under the third Berlusconi government Roberto Maroni, now leader of the Lega Nord, was named Minister of the Interior (Triandafyllidou and Ambrosini 2011). Maroni was able to pass a security package, regarding immigration, some measures of which were so extreme they were ruled unconstitutional by the Italian constitutional court (Triandafyllidou and Ambrosini 2011). This package extended the time that suspected illegal immigrants could be detained under the Bossi-Fini law of 2002, barred them from all administrative acts, and introduced territorial surveillance of citizen patrols (Triandafyllidou and Ambrosini 2011).

The passage of the security package, much of which was revoked by the Constitutional Court, illustrates a point of Albertazzi and McDonnell (2010), that many of the Lega Nord's policy positions are unrealistic, and more of a symbolic "wish list". The ability of the Lega Nord to pass such an extreme measure through a center-right 
controlled government shows their power within it. With winning $8.07 \%$ of the vote they were able to pass legislation that was so extreme it was declared unconstitutional. This is illustrative to the fact that when the Lega has moderated on their spatial demands, they have been able sway the government into passing very extreme protectionist policy stances.

The most glaring example of the LN's coalition potential enabling it to influence the Italian economic agenda was the signing of the August 2008 Treaty of Friendship, Partnership, and Cooperation between Italy and Libya by Silvio Berlusconi and Mommar Gaddafi (Ronzitti 2009). Part of this treaty concerns cooperation in combating illegal immigration, in which Italy provides resources including patrol boats and satellite technology to patrol Libya's coastline through joint forces (Ronzitti 2009). This agreement effectively stopped immigration from Libya to Italy from 2009-2011 (Triandafyllidou and Ambrosini 2011). This agreement made it easier to turn ships carrying illegal immigrants around back to Libya before they have hit Italian shores (Albertazzi and McDonnell 2010; Triandafyllidou and Ambrosini 2011). The agreement has caused many concerns regarding human rights due to this policy and because Libya has not ratified the 1951 Convention on Refugees (Ronzitti 2009; Triandafyllidou and Ambrosini 2011).

This might come as a surprise because many of the business interests that support the PdL depend on the filling of the large amount of low skill jobs by immigrants (Triandafyllidou and Ambrosini 2011). However, this is where the Lega Nord can be seen flexing its muscle with its strong coalition potential. Although the PdL was clearly the dominant player in Berlusconi III, the LN was indispensable, and one way to appease 
them was to give them control over immigration policy. FI did begin to adopt immigration as a larger issue in the Berlusconi governments (Triandafyllidou and Ambrosini 2011; Woods 2010). However, there is a notable difference, as the LN views immigrants as fundamentally different and having cultural differences that cannot be overcome; while other parties believe that the problem is a lack of assimilation among immigrants (Woods 2010). This can be seen in the treatment of asylum seekers in the wake of the Arab Spring. Berlusconi portrayed it as a tragedy while Umberto Bossi demanded the "immigrants out of here" (Triandafyllidou and Ambrosini 2011).

\section{Conclusion}

The data from the Swiss Federal Institute of Technology Zurich seems to suggest that there is no correlation between the actual state of openness in the Italian economy and the Lega Nord's spatial demands. This comes contrary to studies conducted by Haupt (2010) and Ezrow and Helwig (2012). Perhaps this is because the Lega Nord engages in what Cento Bull (2011) describes as "simulative politics" in which symbolism becomes more important than the reality it is supposed to represent. In any case, the lack of a correlation between the Lega's spatial demands and economic openness once again demonstrates the shortcomings of applying generalized models to ethno-regionalist parties. Rich contextual analyses allow for a better understanding of the peculiarities of specific parties.

However, when analyzing the inverse relationship, the impact the Lega Nord's spatial demands have on economic factors, there does appear to be a pattern. This pattern seems to be well explained by Sartori's (1976) theory of coalition potential. In periods when the LN had more moderate spatial demands, they had greater coalition potential 
with other parties on the right. Access to government power and the bargaining power that came with better electoral results gave the Lega the ability to implement protectionist immigration policies that were further right than the positions of FI. This is best exemplified with the 2002 passage of the Bossi-Fini Law, the 2008 Security Package, and the Signing of the Treaty of Friendship, Partnership, and Cooperation between Italy and Libya. Overall, this analysis demonstrates that the oscillation of spatial demands of ethno-regionalist parties can have drastic effects on their ability to make practical impacts on the national economic agenda. 


\section{CHAPTER VIII \\ INTERNAL FACTORS}

\section{Introduction}

This chapter will examine the effect of internal factors on the Lega Nord's change in spatial demands. The first section will review the theory and hypotheses relevant to the internal variables. The first section will utilize qualitative data from history to analyze the impact that Umberto Bossi's personal relationships had on the

party's spatial demands. The subsequent section will qualitatively assess the changes in spatial demands and strategies for achieving those spatial demands that have been brought about by leadership change. The final section will conclude with a summary of findings and their implications. This chapter will provide an in-depth analysis of the role of party leadership in the oscillation of their demands, and provide analysis of party demands at the individual level.

\section{Theory and Hypotheses}

Harmel and Janda's (1994) Integrated Theory of party change suggested that leadership change and change in the dominant party faction both have an effect on party change. These propositions were later found to be significant in an empirical large $\mathrm{N}$ 
study (Harmel, Heo, Tan, and Janda 1995). Later Schumacher, DeVries, and Vis (2013) found that the distribution of power between elites and activists tend to have an effect on party change as well. While I do not doubt the validity of these findings, there has yet to be a study that examines the how the actions at the individual level have had an impact on party change. If a party leader has tight control over the party, then it seems logical that the leaders' actions would have an impact on their party's demands.

Two hypotheses were presented in Chapter III regarding the internal idiosyncrasies of parties. The first hypothesis is that the individual level actions of Umberto Bossi will be a relevant factor for determining the Lega Nord's spatial demands. The second hypothesis is that the leadership of Matteo Salvini will bring about new spatial demands.

\section{Individual Level Actions}

The Lega Nord's concentration of power almost solely on its leader has constrained the ability of the leadership or dominant party faction from changing for almost 30 years. If changes in leadership and dominant party factions have not played a significant role during Bossi's reign as party leader then what internal factor has? For most of the Lega's history power has been concentrated with Umberto Bossi. What role, if any, have the personal actions of Umberto Bossi played in the oscillation of the LN from more moderate to more extreme spatial demands?

Historically speaking, both the Lega Nord and Forza Italia have been under the control of their founders Umberto Bossi and Silvio Berlusconi, respectively. The relationship between the two parties was contentious at the beginning of the Second Republic. However, after the 1999 EP elections the LN and FI formed a close alliance 
(Albertazzi and McDonnell 2005; Massetti and Toubeau 2013). This abrupt turnaround is strange, especially without a leadership change in either party. By Berlusconi III the LN was considered the closest ally to FI, so much so that they were the only party in the coalition that was not given the ultimatum of merging into the PdL or leaving the coalition (Albertazzi and McDonnell 2010). The LN was also rewarded with many key ministries in Berlusconi III for their loyalty (Massetti and Toubeau 2013). Two leaders that once denounced each other were now loyal allies. This section will examine the evolution of the relationship between Bossi and Berlusconi and its impact on the Lega Nord's and whether or not it had an impact on the LN's spatial demands.

When Silvio Berlusconi entered the political arena in 1994 many of the Lega Nord's activists opposed any sort of association with Forza Italia, as Berlusconi conflated with Bettino Craxi, a former prime minister with a reputation tarnished by the Tangentopoli crisis (Cento Bull and Gilbert 2001). However, this did not stop Bossi from forging an electoral pact with Berlusconi, indicating that if it was not for the pact the LN "would have been wiped out" (Cento Bull and Gilbert 2001). This exemplifies the lack of power the Lega's activists had in comparison to Umberto Bossi. While the hardline activists wanted to cling to their fundamental values, Bossi was willing to keep his party alive and maximize its power by any means necessary.

The electoral pact was not the result of a good relationship between the Lega Nord and Forza Italia, however. The relationship was merely convenient for both parties (Cento Bull and Gilbert 2001). The FI still wanted to wipe out the Lega so they would have less competition for the northern electorate, and the activists of the LN still thought FI to be the old guard of corrupt politicians (Cento Bull and Gilbert 2001). It was not 
until the realization that federal reforms were not a high priority of Berlusconi I that Bossi decided to bring down the government (Cento Bull and Gilbert 2001). After this moment the relationship between Bossi and Berlusconi and the LN and FI became hostile (Cento Bull and Gilbert 2001). The majority of the LN opposed the electoral pact, however, it was not until Bossi's relationship with Berlusconi deteriorated that the decision was made to leave the government. It was after this point that the Lega Nord campaigned for secessionism. During this period he made openly provocative comments about FI and Berlusconi.

Bossi was no doubt most loyal to Berlusconi during Berlusconi III. Silvio Berlusconi has been the center piece of political scandals for most of his life as a politician. However, allegations against Berlusconi have become increasingly common from his third government to the present day. Bossi's support even in the face of Berlusconi's scandals is best evidence by his comments to the United States ambassador according to one of the WikiLeaks cables. In regard to allegations that Berlusconi consorted with minors in 2010 Bossi told the US Ambassador that it was likely the work of the mafia setting a political trap for Berlusconi (Lister and Messia 2010). Bossi had no idea that his statement would be publicly leaked. This suggests that his relationship with Berlusconi was not just to convince the public of the coalition's solidarity, and that he was willing to stand by Berlusconi even at the risk of being associated with his scandal.

\section{The Lega Nord and Leadership Change}

The power structure of the Lega Nord historically has been concentrated around its founder Umberto Bossi, a charismatic leader who attracted a populist support base 
(Gilbert 1993; Koff and Koff 2000; Cento Bull and Gilbert 2001; Giordano 2004;

Woods 2010). Bossi was able to attract a broad support base among the industrial areas of Northern Italy by using captivating and energetic speech, capitalizing on his working class background, and his utilization of symbolism. The LN became a quasi-cult of personality revolving around Bossi, and this allowed him to implement a party structure in which he personally had tight control over, leaving almost no room for dissent or critical debate from within (Cento Bull and Gilbert 2001).

There have only been two leadership changes over the history of the Lega Nord, both of which occurred relatively recently. The first switch was from Umberto Bossi to the long time Lega member and current president of Lombardy, Roberto Maroni. Bossi resigned in April of 2012, despite objections from other party members, over a scandal regarding improper use of party funds (D’Emilio 2012). Maroni took over the role of party leader while Bossi took on a lesser role, and stated that he would back Bossi if he chose to resume his role (D'Emilio 2012). Maroni had been a loyal, long time party member and an ally of Bossi. His statement that he would back Umberto Bossi should he choose to run for party leader again showed that this change of leadership was relatively hollow. It was the result of an external circumstance, and Maroni was more of a place holder for Bossi than he was a true change in leadership.

Though during the period when Bossi was no longer leader his control over the party waned. This could possibly be due to his absence from office or as a result of his political scandal. In December of 2013 Umberto Bossi lost the election for party leader to Matteo Salvini (Agence France Presse 2013). Regardless of the cause of Bossi's weakening influence, Matteo Salvini was able to capitalize on it to become the party 
leader. Bossi had tight control over the Lega Nord by concentrating power in himself. Even in the wake of his resignation, his replacement, Roberto Maroni, was loyal to Bossi and did not pose a threat for a possible re-entry into Bossi's old position. However, in abscence, Bossi's control over the party weakened, providing Matteo Salvini the opportunity to seize control. In slightly more than a year and a half's time, Salvini took advantage of the weakening concentration of power within the party to wrestle away what Umberto Bossi controlled for almost three decades.

Although Salvini took control of the party recently there are already observable changes in the Lega Nord's demands and the strategies he is using to obtain them. He has taken a firm stance against the Euro, the EU, and has demanded the secession of Padania (Agence France Presse 2013). Unlike Bossi, who focused his attention primarily on domestic issues, Salvini seems to be taking a pan-European approach to secession. This strategy, though anti-EU, is not anti-European. The Basta Euro campaign, launched during Salvini's leadership, is a tour of political rallies across Italy in opposition to the European common currency. The slogan for the campaign is "Another Europe Is Possible ${ }^{19}$

Salvini's desire for another Europe can be seen in his political strategy. The Lega Nord has begun to make allies outside of Italy in the European Parliament. Currently the LN has joined into an EP coalition with other secessionist and euroskeptic parties, headed by Marine Le Pen's National Front, a French nationalist party (Agence France Presse 2014). The LN now appears to be more involved in separatist and irredentist

\footnotetext{
19 “Un'altra Europa è possibile” Source: http://www.bastaeuro.org/ Date accessed: 09/02/2014
} 92 
movements in Europe as well. Salvini has endorsed the secessionist campaigns of Scotland and Catalonia (Agence France Presse 2014).

If the LN's homepage ${ }^{20}$ is any indication of Salvini's leadership style, it may suggest that he is attempting to create a cult of personality similar to that of Bossi. Image 1 shows the Lega Nord's homepage as of September $2^{\text {nd }} 2014$. The first thing anyone visiting the site sees is two large images of Salvini, one of which being the background that appears on every page of the site. The presence of Salvini on every page of the LN's site suggests that he might have some of the same personalist leadership qualities that Bossi had. This design might suggest that Salvini is the party. However, Bossi's cult of personality took almost three decades to develop.

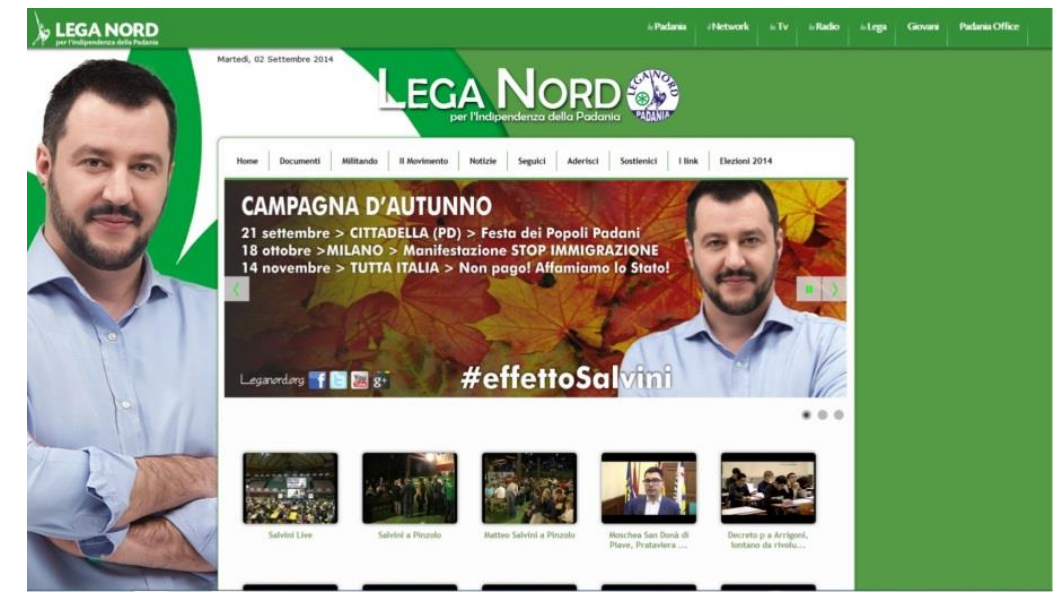

Figure 2: Lega Nord Homepage, September 2 ${ }^{\text {nd }}, 2014$

It is too early to come to conclusions about Matteo Salvini and the degree to which power will be concentrated in him under his leadership. There are some early indicators to suggest that he may continue the Lega Nord's tradition of personalistic leadership. However, the fact that he was able to wrestle power away from Umberto

${ }^{20}$ Source: http://www.leganord.org/ Date accessed: 09/02/2014 
Bossi may suggest that power has now become more dispersed in the party. Time will tell whether Salvini will be the new Bossi or if the Lega's activists will have greater influence on their policy. Regardless of whether or not Salvini's tenure as party leader will represent a drastic reorganization of the party, it is abundantly clear that his leadership has changed the LN's spatial demands, and its international involvement in other secessionist and irredentist movements.

\section{Conclusions}

It can be concluded from this analysis that individual level actions and leadership change have had an impact on the Lega Nord's spatial demands. The study of the party leader is a level of analysis that is frequently ignored by the existent literature. The findings of this study suggest that further analysis of ethno-regionalist parties at the individual-level may be warranted. This study has also found that leadership change has been a relevant factor in oscillations of spatial demands. Although this factor has been previously identified by the literature, it was not until recently that the impact of leadership change could be studied in relation to the Lega Nord.

Without other internal factors constraining Umberto Bossi his personal actions and relationships became an important factor in the Lega Nord's oscillation between moderate and more radical spatial demands. This was particularly true of his relationship with Silvio Berlusconi and his decisions regarding the LN's relationship with FI. Power was so concentrated that Bossi was able to ignore the many activists that opposed an electoral pact with Forza Italia. After the electoral pact was made, Bossi's attitude toward Berlusconi soured after the refusal of Berlusconi I to make federalism a priority in the coalition's agenda. Bossi soon split from the coalition and the Lega began to campaign 
for the secession of Padania. After their electoral misfortunes in 1999 Bossi redeveloped a more amicable relationship with Berlusconi, and soon became the most loyal ally in the coalition. Later, in an attempt not to be conflated with Berlusconi's scandals, Bossi's distanced himself from Berlusconi. Thus, the LN distanced itself from FI. It is evident that the organization of the party has impacted its ability to cooperate and its spatial demands.

Historically, the concentration of power in the LN in Umberto Bossi has constrained the ability of new leaders and factions to arise. Without room for descent, no faction or rival leader could establish itself as a dominant force. For most of the LN's history the only option for those who disagreed with the party's direction was to leave the party. Recent developments have taken power from Bossi and placed it with Matteo Salvini. Salvini has taken the party back on the path to secession, and under his leadership, the LN has become more vocal about self-determination outside of Italy, as well. This version of Padanian self-determination is one that is very different from the one Bossi proposed in the late 90's.It is too early to conclude whether the old power structure has been destroyed permanently, or if the old personalistic structure will be rebuilt around Salvini. However, it is clear with the case of the Lega Nord that new leadership has brought about new spatial demands and a new international approach for achieving these demands. 


\section{CHAPTER IX}

\section{"OTHERING"}

\section{Introduction}

This chapter will examine how the changes in the perceived "other" to the Lega Nord's group identity has impacted the oscillation of their spatial demands between more moderate and more radical spatial demands. The first section will review the relevant literature and hypotheses derived from them. The second section will utilize quantitative data to assess the change in the LN's perception of the other. I have collected this data from the Lega Nord's website, which contains an archive of visual propaganda. The individual pieces are coded to determine what the "other" being presented is (and if there is an "other" being presented). This data will show how the Lega's perceived "other" has changed over time. The following section will present some pieces of visual propaganda from different points in the LN's history and give an in-depth qualitative analysis of how they have changed over time. The chapter will conclude with a summarization of findings and their implications.

\section{Theory and Hypotheses}

It has been argued that for a group to have a unique identity it must have an "other" to which its identity is defined as different from (Abizadeh 2005; Johnson and 
Coleman 2012). The "other" can be defined as, "the intentional construction of a region as different from, perhaps even antithetical to, national norms and values as an element of nation-building" (Johnson and Coleman 2012). Some have argued that this “other" although different, need not be adversarial (Abizadeh 2005). Woods (2011) conducted a visual analysis of the Lega Nord's propaganda which showed that this was not the case. The visual propaganda of the Lega Nord embodies an "us against them" mentality in relation to the "other" (Woods 2011).

Based on the theory of "othering", I hypothesized in Chapter IV that when the Lega Nord has identified the "other" as an "other" inside of Italy they will have more radical spatial demands, while in periods where the Lega Nord has identified an "other" outside of the state its spatial demands would be more moderate. The internal "others" that will be examined in this chapter are Southern Italy, and the corrupt Roman political elite. The external "others" that will be examined are the European Union, immigrants, and globalizing forces. This is not to say that I believe that the LN will shed their Northern identity for that of a radical right wing party, but that external others will be given more consideration.

The hypothesis will be tested with quantitative and qualitative data. The following section will examine quantitative data coded from the Lega Nord's visual propaganda archive posted on its website ${ }^{21}$. This archive contains propaganda organized by date from 2000 to 2014 . The posters have been coded to identify the "other" that is being presented by the LN. The internal "others" are divided into Southern Italy and the

\footnotetext{
${ }^{21}$ Source: http://www.leganord.org/index.php/il-movimento/la-nostrastoria/manifesti?showall=\&limitstart= Date accessed: 09/04/2014
} 
centralized Italian State (Rome). The external others are divided into the EU and immigrants. This dataset systematically show if and how the Lega Nord's perception of the "other" has changed over time.

The section after will analyze select posters over various time periods qualitatively. I will show how the language and images on the poster define the Lega Nord's identity. Comparing visual propaganda quantitatively will show how the LN's conception of the "other" has changed over time. Although this approach is less systematic than the quantitative approach, it will allow the analysis to go further back than the archive has data for. This approach also allows the analysis to disregard propaganda solely political advertising that does not contain any "other".

\section{Quantitative Analysis}

Table 5 presents the results of the coding of the visual propaganda from the archives of the Lega Nord's website from a period of 2000-2014. It shows the number of posters mentioning a specific "other", and the percentage of mentions of internal and external others by year. The internal others are Rome and the South. Propaganda coded with a Roman "other" is that which suggested that politicians were thieving or untrustworthy, or attacked the Italian state or its programs. Anything containing mentions of northern superiority, or disparaging the south or specific southern region was coded as having southern "other". Propaganda that portrayed immigration (legal or illegal), or foreigners inside of Italy as negative was coded as having an immigrant “other”. Posters advocating for insulation from internationalism, or advocating for protectionist economic policies were coded the "other" as the global system. For 
anything that portrayed the EU, the EMU, or its policies as negative the EU was coded as the "other".

Table 5: Frequency of Internal and External Others in the LN's Visual Propaganda ${ }^{22}$

\begin{tabular}{|c|c|c|c|c|c|c|c|}
\hline Year & Rome & South & Internal & Immigrants & $\mathrm{EU}$ & Globalization & External \\
\hline 2000 & 1 & 0 & $25 \%$ & 1 & 2 & 0 & $75 \%$ \\
\hline 2001 & 0 & 1 & $20 \%$ & 3 & 0 & 1 & $80 \%$ \\
\hline 2002 & 0 & 2 & $25 \%$ & 3 & 2 & 1 & $75 \%$ \\
\hline 2003 & 4 & 4 & $50 \%$ & 3 & 1 & 4 & $50 \%$ \\
\hline 2004 & 6 & 1 & $63.6 \%$ & 4 & 0 & 0 & $36.4 \%$ \\
\hline 2005 & 4 & 0 & $66.7 \%$ & 1 & 0 & 1 & $33.3 \%$ \\
\hline 2006 & 6 & 0 & $60 \%$ & 3 & 0 & 1 & $40 \%$ \\
\hline 2007 & 10 & 0 & $100 \%$ & 0 & 0 & 0 & $0 \%$ \\
\hline 2008 & 8 & 1 & $64.3 \%$ & 5 & 0 & 0 & $35.7 \%$ \\
\hline 2009 & 1 & 0 & $25 \%$ & 2 & 0 & 1 & $75 \%$ \\
\hline 2010 & 1 & 0 & $100 \%$ & 0 & 0 & 0 & $0 \%$ \\
\hline 2011 & 1 & 0 & $20 \%$ & 2 & 1 & 1 & $80 \%$ \\
\hline 2012 & 3 & 0 & $75 \%$ & 1 & 0 & 0 & $25 \%$ \\
\hline $2013 / 2014$ & 1 & 0 & $16.7 \%$ & 2 & 3 & 0 & $83.3 \%$ \\
\hline
\end{tabular}

The data supports the hypothesis that the Lega Nord tends to prioritize their classification of the "other" externally over the period of 2000-2006. In some cases external "othering" is actually more frequent than internal "othering". Table 5 shows this to be the case between the years of 2000 and 2002. This is interesting as the LN founded its identity on the basis of "othering" Rome and the South. The hypothesis

\footnotetext{
${ }^{22}$ Visual propaganda accessible at: http://www.leganord.org/index.php/il-movimento/la-nostrastoria/manifesti Date accessed: 09/04/2014
} 
would suggest also that this is to be expected. In the period 2001-2006 the Lega Nord was advocating for devolution of power to the regions, the most moderate spatial demands they have had in their history (Cento Bull 2011).

However, the data from the rest of the table does not seem to support the hypothesis. In 2007 external "othering" dropped to $0 \%$. This may be due to the fact that they were out of government for the entirety of this year. In fact, much of the propaganda during this year was aimed specifically at Romano Prodi, the Prime Minster of a government the Lega was in opposition to. Rather than an "othering" of Rome this may have just been political attacks advertisements. This refocusing may have been more of an electoral strategy more than anything else.

This does not explain for the rest of the later dates, especially in 2014. Based on the hypothesis one could expect that in a period of secessionist demands there would be little mention of external "others". However, $83.3 \%$ of the "othering" taking place is external, and much of it focused on the EU. This might be due to the change in leadership that occurred in December of 2013 from Roberto Maroni to Matteo Salvini. During Salvini's leadership the Lega Nord website has displayed advertisements for Salvini's Basta Euro tour. This seems consistent with the new secessionist strategy that Salvini has implemented. Along with calls for secession, Salvini has viciously criticized the EU and declared the Euro "a crime against humanity" (Agence France Presse 2013). He has begun to create a coalition in the European parliament in order to create a 
"different Europe" (Agence France Presse 2014). This is consistent with the slogan of the Basta Euro tour, "Another Europe Is Possible"23.

Salvini is taking a pan-European approach to secessionism, one that requires the allies of other secessionist movements and radical right wing parties in Europe. Salvini publicly supports the secession of Scotland and Catalonia, and a Europe with less power concentrated in the EU and the states and more with the regions (Agence France Presse 2014). In the EP, the Lega Nord has entered a political alliance with several other Euroskeptic parties led Marine Le Pen and the National Front party of France (Dahlburg 2014). In an interview posted on the LN's website and YouTube channel entitled "Salvini with Le Pen Together Against a Europe That We Broke" ${ }^{24}$ Salvini objects European immigration and economic policy, stating the need to protect Italian and French markets from foreign goods.

The quantitative analysis disproved my hypothesis that the Lega Nord's spatial demands would be more radical when the "other" was conceptualized as internal than when it is conceptualized as external. However, this does not necessarily mean that "othering" has no relation to spatial demands. The "other" that the party conceptualizes may be impacted by the identified spatial demands and strategies to achieve those demands of the party. This conclusion should not be hastily reached, though. This would be an interesting topic for future research, as time progresses and more information become available about the strategies for "othering" Matteo Salvini will employ.

\footnotetext{
23 "Un'altra Europa è possibile" Source: http://www.bastaeuro.org/ Date accessed: 09/02/2014

${ }^{24}$ Source: "Salvini Con Le Pen Insieme Contro Europa Che Ci Ha Rotto" < https://www.youtube.com/watch?v=IsaIaPtJZ4Q> Date accessed: 09/04/2014
} 


\section{Qualitative Analysis}

Unfortunately the Lega Nord's online archive does not contain visual propaganda from before 2000. For this reason, a systematic quantitative analysis would be inappropriate to observe how the LN has changed its perception of the "other" over its entire history. However, Davide Caparini, a Lega Nord politician, has an extensive archive of Lega Nord propaganda from its earlier years ${ }^{25}$. This archive does not organize the posters chronologically or give them all dates, as the Lega Nord's website does. Therefore, I cannot code these by year and add them to the previous chapter's analysis. However, this archive creates the opportunity to conduct a qualitative analysis by selecting specific posters from different time periods to give both a visual and contextualized understanding about how the perception of the "other" has changed over the course of its history, and how it has coincided with its spatial demands.

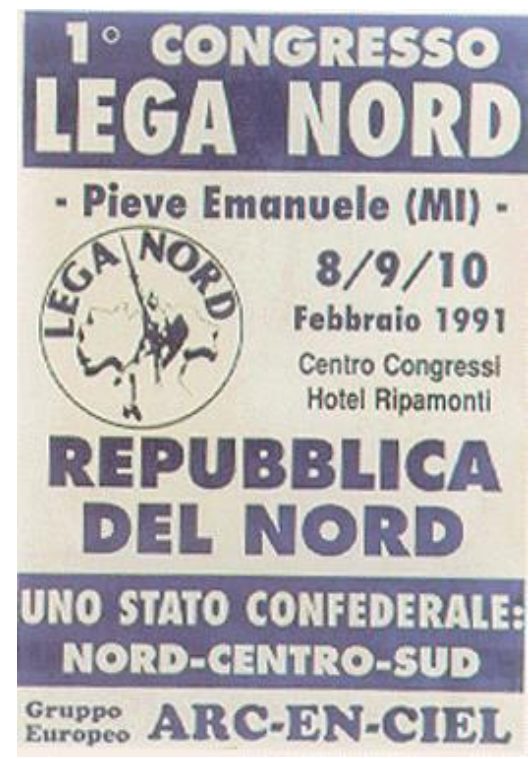

Figure 3: 1991 Advertisement for the $1^{\text {st }}$ Congress of the Lega Nord

\footnotetext{
${ }^{25}$ Archive accessible at: <http://www.caparini.com/propaganda/manifesti\%20lega.htm" Date accessed: $09 / 13 / 2014$
} 
Source: < http://www.caparini.com/propaganda/manifesti\%20lega.htm> (Accessed 9/13/2014)

This first image is promoting the $1^{\text {st }}$ Lega Nord Congress, held on February 8$10^{\text {th }}, 1991$. Visually the "othering" of south and central Italy can be seen in the symbol of Il Giramento di Pontida being superimposed over an image of Northern Italy. Beneath the logo is the phrase "Reppublica Del Nord" (Republic of the North). It is important to note that in 1991 the $\mathrm{LN}$ was not campaigning for secession, but federalism (Cento Bull and Gilbert 2001). In their earlier years the LN campaigned for a more radical form of federalism that would create three separate confederal regions (Cento Bull and Gilbert 2001). This is indicated on the poster in the phrase "Uno Stato Confederale: Nord-Centro-Sud"' (One Confederal State: North-Center-South". This poster does more than suggest that the Italian state should be reorganized. The phrase "Repubblica Del Nord" suggests that this arrangement will benefit the North specifically. This arrangement, proposed by the Lega Nord, for the interests of Republic of the North, identifies Southern and Central Italy as the "other". 


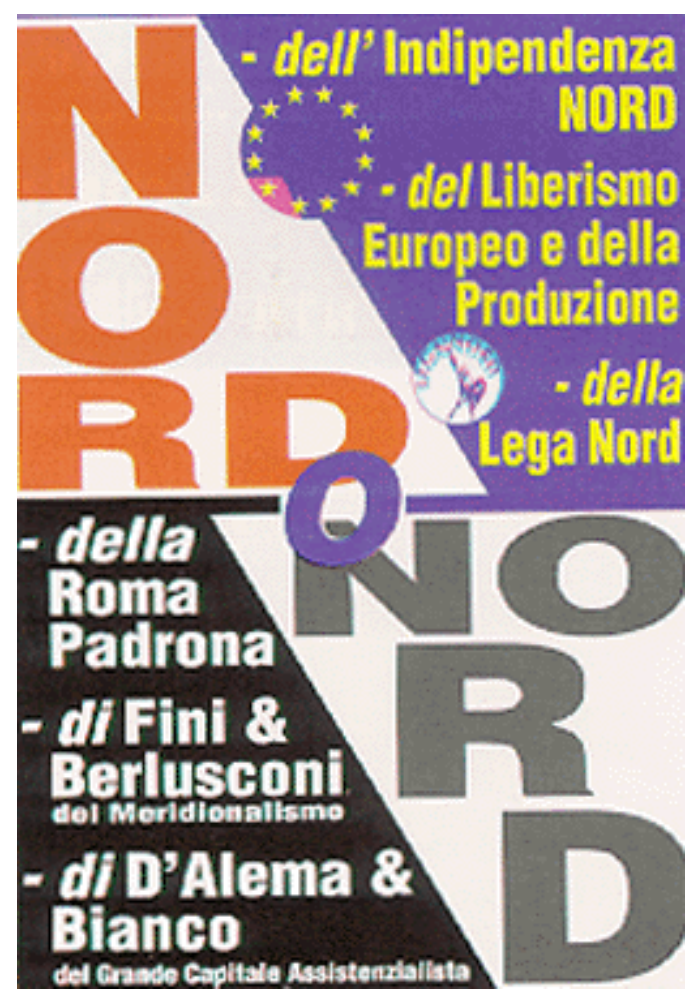

Figure 4: Lega Nord Poster from the $1^{\text {st }}$ Secession Period

Source: < http://www.caparini.com/propaganda/manifesti\%20lega.htm > (Accessed 9/13/2014)

Image 3 is from the period of 1996-1999, after the fall of Berlusconi I, the first time the Lega Nord openly campaigned for secession. This poster presents two alternatives for the North. The first, in the bright colors of the flag of the EU, the North of Northern independence, of European liberalism and production, and of the Lega Nord. The alternative, in colored bleak black and white, is the North of master Rome, of Fini, Berlusconi, and the Southerners, and of D'Alema and Bianco (politicians of the Italian left), big capital, and welfarism.

The contrast between good and bad is immediately noticeable visually due to the contrast of color. Northern independence, European liberalism and production, and the Lega Nord appear in bright visually appealing colors. They are in the colors of the EU 
flag, which suggests a glorification of Pan-Europeanism, which is interesting considering the EU will later be identified by the Lega Nord as a political enemy. It was during this period that the LN and several other European separatist groups adopted the framework of a "Europe of Regions", which would utilize the EU as a platform to increase the power of the regions of Europe versus their respective states (Giordano 2001; Giordano 2004). The top portion of this poster identifies the North with the Lega and with a regional EU.

The bottom portion, by contrast, is in black and white, making it visually seem bleak. The bleak future of the North is characterized as being enslaved to master Rome, and the politicians of the South, big capital, and welfarism. Placing the politicians and the centralized state in dark colors and describing them in a negative light characterizes an internal "other" as politicians and Rome. This poster suggests that the EU and Northern secession are ways to rid the North of the Roman "other".

Image 4 is an advertisement from 2001 for a Lega Nord immigration rally. It reads "Stop! Illegals and Delinquency" had has the word "Basta” (enough) superimposed over a picture of two men. One of the men is masked and holding a firearm, the other is breaking into something with a crowbar. This poster is meant to equate illegal immigration and crime together, thus rendering illegal immigration a security issue. The word STOP in all capital letters makes the issue of immigration seem urgent as well. The Lega Nord presents immigrants as the "other" in this poster by presenting them as a security threat. It is important to note that in 2001 the Lega Nord was in its least radical period of spatial demands, calling for devolution (Cento Bull 2011). Identifying a common external "other" with Forza Italia and the Allienza 
Nazionale aided the Lega Nord in being able to cooperate within the CdL by calling for more moderate spatial demands. This made the coalition much more stable than in Berlusconi I.

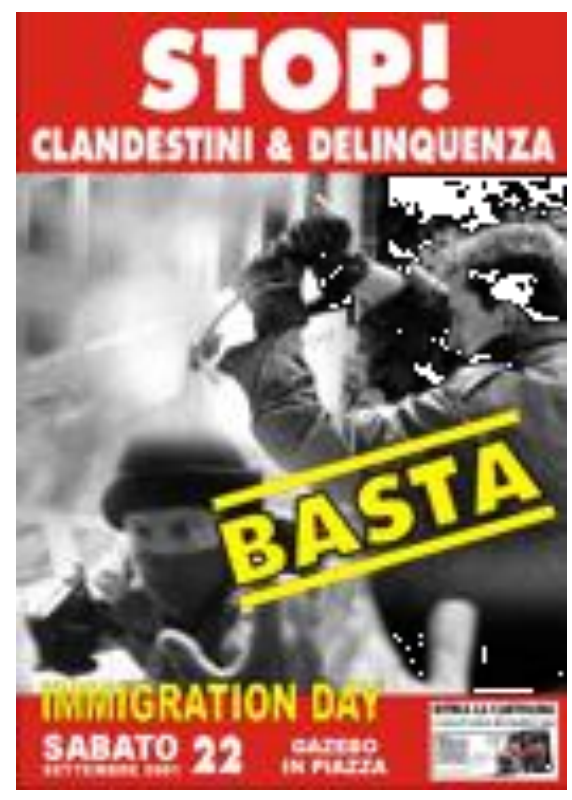

Figure 5: Advertisement for Lega Nord Immigration Day

Source: < http://www.caparini.com/propaganda/manifesti\%20lega.htm> (Accessed 9/13/2014)

Image 5, from 2009, is a photograph of a boat packed with illegal immigrants with the phrase "Abbiamo Fermato L'invasione" (We stopped the invasion) over it. This poster is a way for the Lega Nord to take credit for their role in creating highly restrictive immigration policy. As mentioned in Chapter VII, the LN played an instrumental role in the passage of the 2008 Security Package, laws containing extreme measures in response to illegal immigration (Triandafyllidou and Ambrosini 2011). The use of the word "invasion" to describe illegal immigration frames the issue as a security threat. The LN tries to portray itself in a heroic light by claiming that it defended against this threat. This creates a contrast in the poster by identifying the Lega Nord as 
heroic defenders against the invasion of the immigrant "others". It is important to note at this time the $\mathrm{LN}$ was in coalition with Berlusconi and the PdL, and they were campaigning on fiscal federalism (Cento Bull 2011).

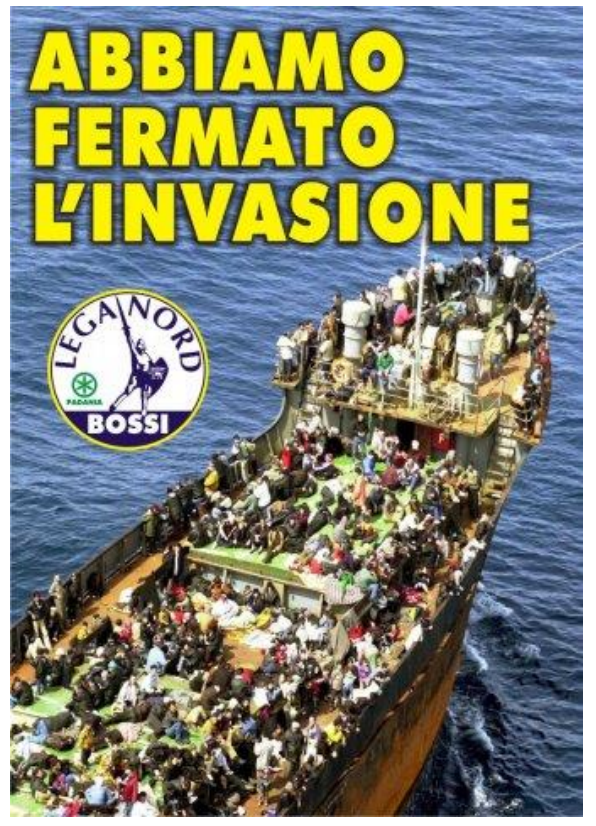

Figure 6: "We Stopped the Invasion"

Source: < http://www.caparini.com/propaganda/manifesti\%20lega.htm > (Accessed 9/13/2014)

Image 6 is an advertisement for Matteo Salvini's Basta Euro Tour from May of 2014. "Basta Euro" (Enough of the Euro) clearly opposes further EU integration, specifically in the sector of the EMU. This signifies a shift in the Lega Nord's "othering" to the EU. However, this anti-EU stance does not seem to be the same as the anti EU stance taken in the early 2000s under Umberto Bossi. Image 6 reads "Pontida Un'Altra Europa è Possibile" (Pontida another Europe is Possible). This "others" the EU, but it does not "other" Europe.

This suggests that the Lega Nord may be reverting back to the logic of the "Europe of regions". The LN had previously used this logic in their secessionist period 
between 1996 and 1999, and took a pro EU stance (Giordano 2004). After the

realization that the EU gave little power to the regions, the Lega Nord took a decisively anti-European stance (Giordano 2004). The idea of the "Europe of regions seems to be arising again in LN ideology, but this Europe of regions does not include the EU, which they appear to view as a failed experiment in Pan-Europeanism.

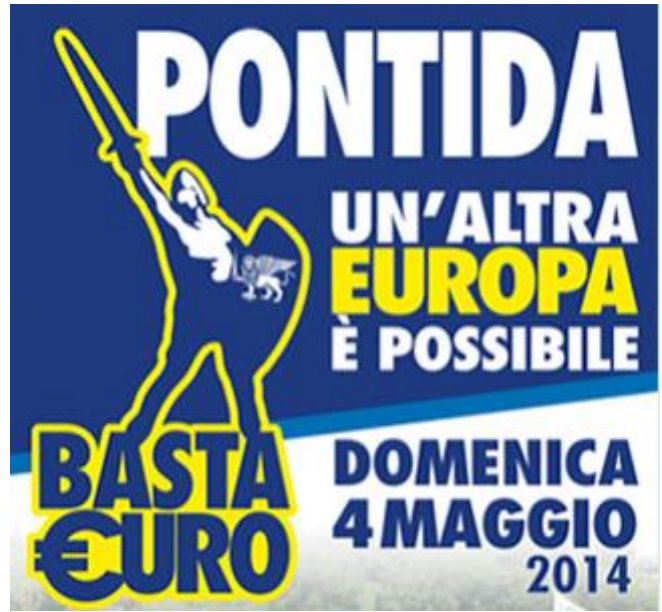

Figure 7: Advertisement for Matteo Salvini's Basta Euro Tour

Source: < http://www.caparini.com/propaganda/manifesti\%20lega.htm> (Accessed 9/13/2014)

\section{Conclusions}

The quantitative analysis did not support the hypothesis that that when the Lega Nord has identified the "other" as an "other" inside of Italy they will have more radical spatial demands, while in periods where the Lega Nord has identified an "other" outside of the state its spatial demands would be more moderate. This could have possibly been the case under the leadership of Umberto Bossi. However, under the leadership of Matteo Salvini this dynamic seemed to change, as he mainly identified external "others" in a period of secession. From this data it cannot be concluded that "othering" has a direct effect on spatial demands. 
This does not necessarily mean that spatial demands and "othering" are not related. The qualitative analysis supported the idea that an "other" can be used as a tool of propaganda to justify changes in territorial demands. The change in the Lega Nord's other when compared to the spatial demands seem to suggest that the inverse is true. The spatial demands will have an impact on the "other" as it can be used to justify a territorial claim or divert attention from a more radical goal made previously. 


\section{CHAPTER X \\ CONCLUSIONS AND IMPLICATIONS}

\section{Introduction}

This chapter will make concluding remarks about the results of the analyses of this study. The sections will review the relevant hypotheses and whether they were confirmed or not by the analysis. This will be followed by a discussion of what can be inferred from the data analyses. Finally, the sections will suggest topics for future research. The sections will review electoral, economic, and internal factors, and “othering" in relation to the Lega Nord's oscillation between more moderate and more radical spatial demands. The final section will make general conclusions about ethnoregionalist parties and the merits and detriments of applying generalized models of party demands to them.

\section{Electoral Factors}

It was hypothesized in Chapter VI that oscillations in spatial demands of the Lega Nord will be adjusted in order to maximize votes. The data from the EEC seemed to confirm this. Changes in the LN's spatial demands tended to occur when they experienced an electoral shock, either in the general or European Parliament elections. This suggests that the Lega does behave as a vote seeking party, and that their primary 
goals can be altered for electoral viability. Somer-Topcu (2009) claimed that with party change comes an uncertain risk. Electoral information can be a source of information that will aid in the party's decision of whether or not to assume that risk. The results of electoral data analysis support this claim.

In the analysis of electoral factors it was also hypothesized that the Lega Nord will oscillate its spatial demands when other parties begin to adopt similar stances on issues, specifically in regard to federalism. Though this did appear to be the case when comparing Forza Italia's stances on federalism with the Lega Nord in the 1990s, this was not the case after the turn of the century. This does not necessarily imply that there is no correlation between the LN's spatial demands and the positions of other political parties. The relationship changed between the Lega and the FI following the EP elections of 1999, changing from that of political adversaries to political allies.

The analysis of the data from the Comparative Manifesto Project suggests that there is a different dynamic between the policy positions of other parties, and their demands when their relationship changes. The Lega Nord seemed to push for more radical spatial demands as the FI began to address federalism in the 90s. However, after the $\mathrm{LN}$ and FI entered into the CdL together they began to converge on the issue of federalism. Adams and Somer Topcu (2009) found that parties tend to move in the same direction as other parties are shifting within their own ideological family. The analysis of the Lega Nord suggests that this is only the case when the two parties within the ideological family are on amicable terms. 


\section{Economic Factors}

Based on the logic that the Lega Nord behaved as a vote seeking party which engaged in simulative politics it was hypothesized in Chapter VII that there will be no correlation between the openness of the Italian economy and its spatial demands. When examining the KOF coefficient of economic openness for Italy, there does not appear to be any relation with the LN's spatial demands. This supports my hypothesis and further supports the argument that the Lega Nord behaves as a vote seeking party.

However, the qualitative analysis of the Lega Nord's political behavior suggests that the inverse is true. The LN's spatial demands have impacted the party's ability to direct Italian economic policy. If a party does not have adequate coalition potential, then it will not form a coalition, and thus they will not be able to effect policy from inside the government (Sartori 1976). In periods when the Lega Nord had more radical spatial demands, it had less coalition potential because FI and the AN were in support of the preservation of the territorial boundaries of the Italian state. However, when the LN moderated its spatial demands it was able to gain prominent positions inside governing coalitions and was better equipped to implement its economic agenda. This was most clearly manifested in the Lega Nord's role in creating protectionist legislation in the areas of foreign labor and immigration.

\section{Internal Factors}

Based on the logic of the Lega Nord being a personalist party, it was hypothesized in Chapter VIII that the individual level actions of Umberto Bossi would be a relevant factor regarding the change in the LN's spatial demands. This hypothesis was supported from a historical qualitative analysis of how Umberto Bossi's personal decisions and 
relationships related with various periods of spatial demands. For most of the Lega Nord's history there has been no change in leadership, dominant party faction, or internal power structure. This provides a unique opportunity to conduct an individual level analysis of Umberto Bossi while controlling for these previously identified internal factors. This study finds that changes originating in the party leader can have an impact on spatial demands, even if there is no change in the leadership itself.

The Lega Nord was able to quickly make shifts between federalism and secession because of the personal relationship formed between Umberto Bossi and Silvio Berlusconi. Many of the party activists opposed electoral pacts with FI at first (Cento Bull and Gilbert 2001). However, since Bossi had tight control over the party he was able to ignore these activists and make decisions that he thought to be prudent and electorally viable for the LN. Historically, the concentration of power in the Lega Nord have made the individual level actions of its leader an important factor that has impacted its spatial demands.

Based on previous theories, this study hypothesized that change in the party leadership has an impact on changes in the Lega Nord's spatial demands. This hypothesis seemed to be confirmed through a qualitative analysis. Under the leadership of Matteo Salvini, the LN is once again on the path of secessionism. The qualitative analysis also revealed that this is not only a switch in spatial demands, but a switch in strategy to achieve these demands as well. Bossi had focused on the secession of Padania primarily as an internal affair in Italy. Salvini has made efforts for regional empowerment at the EU level and has become involved in many secessionist and irredentist movements across Europe. 


\section{"Othering"}

In the previous chapter the impact of "othering" was examined in relation to spatial demands. It was hypothesized that when the Lega Nord has identified the "other" as an "other" inside of Italy they will have more radical spatial demands, while in periods where the Lega Nord has identified an "other" outside of the state its spatial demands would be more moderate. The quantitative analysis of visual propaganda did not support this hypothesis. However, the qualitative analysis of posters did shed some insight onto this relationship. The change in the "other" that the Lega Nord defines may not be a result of the change in their spatial demands, but may be used as a tool for the justification of their spatial demands. Examining how "othering" is used as a justification for spatial demands would be an interesting topic for future research on other ethnoregionalist parties.

\section{Conclusion}

The recent referendum for Scottish independence is a reminder that ethnoregionalism is still a powerful political force in Europe. Recent trends, both at the state and EU level warrant the need for further understanding of how ethno-regionalist parties function. This study has identified factors that relate to the spatial demands of ethnoregionalist parties. There are many studies relating to party demands in general, but few that look at the idiosyncrasies of ethno-regionalist parties.

Some of the analyses of this study, specifically those regarding electoral and economic factors, have shown that the generalized models of party demands do not necessarily fit ethno-regionalist parties. Smaller scale studies of ethno-regionalism could offer more insight onto how these parties are abnormal in some respects. Chapter VIII 
demonstrated that previous studies overlooked actions at of individual leaders. This is a level of analysis frequently overlooked in large $\mathrm{N}$ quantitative studies. Both the analysis of internal factors and "othering" were able to give deep contextual insight into how these mechanisms were related to the oscillation of spatial demands. Ethno-regionalist parties are a specific sub-category of political party. Therefore, to truly understand how these parties function, more contextualized studies would be appropriate. 


\section{REFERENCES}

Abizadeh, Arash. 2005. "Does Collective Identity Presuppose an Other? On the Alleged Incoherence of Global Solidarity". American Political Science Review 99 (February): 45-60.

Adams, James, Michael Clark, Lawrence Ezrow, and Garrett Glasgow. 2006. "Are Niche Parties Fundamentally Different from Mainstream Parties? The Causes and the Electoral Consequences of Western European Parties' Policy Shifts, 1976-1998." American Journal of Political Science 50 (3): 513-529.

Adams, James, and Zeynep Somer-Topcu. 2009. "Policy Adjustment by Parties in Response to Rival Parties' Policy Shifts: Spatial Theory and the Dynamics of Party Competition in Twenty-Five Post-War Democracies." British Journal of Political Science 39 (October): 825-846.

Agence France Presse. 2013. "Italy's Northern League party names new leader". December. Note: News Briefing

Agence France-Presse. 2014. "Catalonia, Scotland, Venice? Italian party eyes autonomy." February. Note: News Briefing

Agnew, John A. 2002. Place and Politics in Modern Italy. Chicago: University of Chicago Press.

Albertazzi, Daniele. 2006. “'Back to Our Roots' or Self-Confessed Manipulation? The Uses of the Past in the Lega Nord's Positing of Padania". National Identities 8 (March): 21-39.

Albertazzi, Daniele \& Duncan McDonnell. 2005. "The Lega Nord in the Second Berlusconi Government: In a League of Its Own”. West European Politics 28 (August): 952-972.

Albertazzi, Daniele \& Duncan McDonnell. 2010. “The Lega Nord Back in Government”. West European Politics 33 (October): 1318-1340.

Aldrich, John H. 1995. Why Parties? The Origin and Transformation of Party Politics in America. Chicago: Chicago University Press. 
Breslin, Shaun. 2008. "Do leaders matter? Chinese politics, leadership transition and the 17th Party Congress." Contemporary Politics 14 (June): 215-231.

Brødsgaard, Kjeld Erik, and Nis Grünberg. 2013. "Leadership Changes and Structural Reform After the 18th Party Congress in China." Copenhagen Journal of Asian Studies 31 (1): 81-94.

Cento Bull, Anna and Mark Gilbert. 2001. The Lega Nord and the Northern Question in Italian Politics. New York: Palgrave.

Cento-Bull, Anna. 2009. "Lega Nord: A Case of Simulative Politics?". South European Society and Politics 14 (June): 129-146.

Cento-Bull, Anna. 2011. "Breaking Up the Post-War Consensus: The Ideology of the Lega Nord in the Early 1990s". Italianist 31 (1): 112-122.

Coleman, Edward. 1996. “Italy’s first Northern League?”. History Today 46 (October): 6-8.

Collier, David. 1993. "The Comparative Method”. In Ada W. Finifter, ed. Political Science: The State of the Discipline. Washington, D.C.: American Political Science Association.

Dandoy, Régis. 2009. “An understudied category of ethno-regionalist parties in Europe: the case of the rattachist parties". IPSA World Congress of Political Science Santiago, 12-16 July 2009. <http://dev.ulb.ac.be/sciencespo/dossiers_membres/dandoy-regis/fichiers/dandoyregis-publication71.pdf $>$

Dandoy, Régis. 2010. "Ethno-Regionalist Parties in Europe: a Typology”. Perspectives on Federalism 2 (2): 194-220

Evans, Jocelyn A. J. 2002. "In Defence of Sartori: Party System Change, Voter Preference Distributions and Other Competitive Incentives". Party Politics 8 (2): $155-174$.

Ezrow, Lawrence, Catherine De Vries, Marco Steenbergen, and Erica Edwards. 2011. "Mean voter representation and partisan constituency representation: Do parties respond to the mean voter position or to their supporters?." Party Politics 17 (May): 275-301. 
Ezrow, Lawrence and Timothy Hellwig. 2012. "Responding to Voters or Responding to Markets? Political Parties and Public Opinion in an Era of Globalization". Political Studies Quarterly.

Fitjar, Rune Dahl. 2010. The Rise of Regionalism: Causes of Regional Mobilization in Western Europe. New York: Routledge.

Gilbert, Mark. 1993. "Warriors of the New Pontida: The Challenge of the Lega Nord to the Italian Party System”. Political Quarterly 64 (January): 99-106.

Giordano, Benito. 2001. "'Institutional thickness', Political Sub-Culture and the Resurgence of (the 'new') Regionalism in Italy: A Case Study of the Northern League in the Province of Varese". Transactions of the Institute of British Geographers 26 (1): 2541.

Giordano, Benito. 2004. "The Politics of the Northern League and Italy's Changing Attitude Towards Europe". Perspectives on European Politics and Society 5 (1): 61-79.

Gould, Andrew C. and Anthony M. Messina. 2014. Europe's Contending Identities: Supranationalism, Ethnoregionalism, Religion, and New Nationalism. New York: Cambridge University Press.

Harmel, Robert and Kenneth Janda. 1994. "An Integrated Theory of Party Goals and Party Change”. Journal of Theoretical Politics 6 (3): 259-287.

Harmel, Robert, Uk Heo, Alexander Tan, and Kenneth Janda. 1995. "Performance, Leadership, Factions and Party Change: An Empirical Analysis". West European Politics 18 (January): 1-33.

Haupt, Andrea B. 2010. "Parties' Responses to Economic Globalization". Party Politics 16(1): 5-27.

Johnson, Corey and Amanda Coleman. 2012. "The Internal Other: Exploring the Dialectical Relationship Between Regional Exclusion and the Construction of National Identity". Annals of the Association of American Geographers 102 (4): 863-880.

Katz, Richard S., and Peter Mair. 1994. How Parties Organize. Change and Adaptation in Party Organizations in Western Europe. London: Sage publishers. 
Koff, Sondra Z., Stephen P. Koff. 2000. Italy: From the First to the Second Republic. New York: Routledge.

Lijphart, Arend. 1971. "Comparative Politics and the Comparative Method". The American Political Science Review 65 (September): 682-693.

Massetti, Emanuele and Arjan H. Schakle. 2013. "Ideology matters: Why Decentralisation Has a Differentiated Effect on Regionalist Parties' Fortunes in Western Democracies”. European Journal of Political Research 52: 797-821.

Massetti, Emanuele and Simon Toubeau. 2013. "Sailing with Northern Winds: Party Politics and Federal Reforms in Italy". West European Politics 36 (February): 359-381.

Paasi, Anssi. 2009. “The Resurgence of the 'Region' and 'Regional Identity': Theoretical Perspectives and Empirical Observations on Regional Dynamics in Europe”. Review of International Studies 35: 121-146.

Panebianco, Angelo. 1988. Political Parties: Organization and Power. Cambridge: Cambridge University Press.

Richarson, John E. and Monica Colombo. 2013. "Continuity and change in antiimmigrant discourse in Italy: An analysis of the visual propaganda of the Lega Nord". Journal of Language and Politics 12 (2): 180-202.

Sartori, Giovanni. 1976. "The Numerical Criterion". Parties and Party Systems: A Framework for Analysis. Cambridge: Cambridge University Press: 119-130.

Sartori, Giovanni. 1991. "Comparing and Miscomparing”. Journal of Theoretical Politics 3 (July): 243-257.

Schumacher, Gijs, Catherine E. de Vries, and Barbara Vis. 2013."Why Do Parties Change Position? Party Organization and Environmental Incentives." Journal of Politics 75 (April): 464-478.

Somer-Topcu, Zeynep. 2009. "Timely Decisions: The Effects of Past National Elections on Party Policy Change". The Journal of Politics 71 (January): 238-248.

Strmiska, Maxmilián. 2002. “A Study on Conceptualisation of (Ethno) regional Parties”. Central European Political Studies Review 14(3): 2-3. 
Türsan, Huri. 1998. "Ethnoregionalist parties as ethnic entrepreneurs" in: De Winter, Lieven, Türsan, Huri (eds.): Regionalist Parties in Western Europe, Routledge, London: 1-16.

Waters, Sarah. 1994. "'Tangentopoli' and the Emergence of a New Political Order in Italy." West European Politics 17 (1).

Woods, Dwayne. 2009. "Pockets of Resistance to Globalization: The Case of the Lega Nord". Patterns of Prejudice 43 (2): 161-177.

Woods, Dwayne. 2010. “A Critical Analysis of the Northern League's Ideographical Profiling”. Journal of Political Ideologies 15 (June): 189-219. 